Article

\title{
New Insights into the Electrocatalytic Mechanism of Methanol Oxidation on Amorphous Ni-B-Co Nanoparticles in Alkaline Media
}

\author{
Fanhua Wu ${ }^{1,2}$, Zhonglin Zhang ${ }^{1}$, Fusheng Zhang ${ }^{1}$, Donghong Duan ${ }^{1}, \mathrm{Yu} \mathrm{Li}^{1}{ }^{1}$, Guoqiang Wei ${ }^{1}$, \\ Shibin Liu ${ }^{1, *} \mathbb{C}$, Qinbo Yuan ${ }^{3,4, *}$, Enzhi Wang ${ }^{3,4}$ and Xiaogang Hao ${ }^{1}$ \\ 1 Department of Chemical Engineering, Taiyuan University of Technology, Taiyuan 030024, China \\ 2 School of Science, North University of China, Taiyuan 030051, China \\ 3 The State Key Laboratory of Hydroscience and Engineering of Tsinghua University, Beijing 100084, China \\ 4 Sanjiangyuan Collaborative Innovation Center, Tsinghua University, Beijing 100084, China \\ * $\quad$ Correspondence: sbliu@tyut.edu.cn (S.L.); qbyuan@tpeco.cn (Q.Y.); Tel./Fax: +86-351-6018554 (S.L.)
}

Received: 18 August 2019; Accepted: 2 September 2019; Published: 5 September 2019

check for updates

\begin{abstract}
Despite an increased interest in sustainable energy conversion systems, there have been limited studies investigating the electrocatalytic reaction mechanism of methanol oxidation on Ni-based amorphous materials in alkaline media. A thorough understanding of such mechanisms would aid in the development of amorphous catalytic materials for methanol oxidation reactions. In the present work, amorphous Ni-B and Ni-B-Co nanoparticles were prepared by a simple chemical reduction, and their electrocatalytic properties were investigated by cyclic voltammetry measurements. The diffusion coefficients $\left(D_{0}\right)$ for $\mathrm{Ni}-\mathrm{B}, \mathrm{Ni}-\mathrm{B}-\mathrm{Co}_{0.02}, \mathrm{Ni}-\mathrm{B}-\mathrm{Co}_{0.05}$, and $\mathrm{Ni}-\mathrm{B}-\mathrm{Co}_{0.1}$ nanoparticles were calculated to be $1.28 \times 10^{-9}, 2.35 \times 10^{-9}, 4.48 \times 10^{-9}$ and $2.67 \times 10^{-9} \mathrm{~cm}^{2} \mathrm{~s}^{-1}$, respectively. The reaction order of methanol in the studied transformation was approximately 0.5 for all studied catalysts, whereas the reaction order of the hydroxide ion was nearly 1 . The activation energy (Ea) values of the reaction were also calculated for the Ni-B and Ni-B-Co nanoparticle systems. Based on our kinetic studies, a mechanism for the methanol oxidation reaction was proposed which involved formation of an electrocatalytic layer on the surface of amorphous Ni-B and Ni-B-Co nanoparticles. And methanol and hydroxide ions could diffuse freely through this three-dimensional porous conductive layer.
\end{abstract}

Keywords: methanol electrooxidation; amorphous Ni-B nanoparticle; cobalt doping; reaction mechanism; kinetics

\section{Introduction}

Direct methanol fuel cells (DMFCs) have become popular for use in portable electronic devices, such as cell phones and laptops as well as in the transportation sector, due to their high energy density and quick refueling characteristics [1,2]. However, DMFCs typically require expensive and scarce noble metal Pt-Ru catalysts at the anode for methanol oxidations; hence, there is a demand for the design of highly efficient and cost-effective alternatives [3-5]. Nickel, a transition metal, is cheap and abundant. Ni-based catalysts which are currently regarded as one of the most promising alternatives due to their respectable electrocatalytic activity toward methanol oxidations under alkaline conditions $[6,7]$. Although methanol oxidations using Ni electrodes in alkaline media have been reported as early as the 1970s [8], it only began to attract increased attention in more recent years.

Catalysts of different morphologies, dopant atoms, particle sizes, and substrates have been studied in an effort to improve their electrocatalytic methanol oxidation reactivity. Recently, heterostructures composed of $\mathrm{Ni}$ cores partially encapsulated within the surface-oxidized layers of $\mathrm{NiO}$ were synthesized with low Ni loadings, exhibiting enhanced catalytic activity and stability for methanol oxidations [9]. 
Moreover, bimetallic Fe-Ni nanoparticles synthesized using a multistep procedure under ambient conditions in water also showed enhanced catalytic activity for methanol oxidations under alkaline conditions compared to the monometallic Fe and Ni nanoparticles [10]. The Li research group reported the simultaneous encapsulation of $\mathrm{Ni}$ and different metal salen complexes in mesoporous zeolite $\mathrm{A}$ via a flexible ligand method. The resulting compound showed much higher electrocatalytic activity for methanol oxidation than pure Ni salen A due to an identified synergetic effect [11,12]. Peng et al. developed a simple solvothermal method for in situ growth of Ni-Se nanowire arrays on Ni foil [13], then through a hydrothermal process/annealing treatment first synthesized the hierarchical nickel oxide nanosheet@nanowire arrays on nickel foam (NiO NS@NW/NF). Notably, these catalysts all exhibited high electrocatalytic activity and stability [14].

For crystalline materials, high densities of atomic steps, ledges, and kinks typically acted as active sites for breaking the chemical bonds [15], that is, unsaturated atom is the catalysis essence of a catalyst. As such, bulk Ni has not been known to shown catalytic activity for methanol oxidations [16]. Therefore, over the past 10 years, Ni-B and Ni-P amorphous materials with more unsaturated atoms have been increasingly recognized as desirable catalysts in the field of methanol oxidation. Amorphous Ni-B and $\mathrm{Ni}-\mathrm{Cu}-\mathrm{P}$ alloys, for example, exhibited superior catalytic stability for methanol oxidation compared to Ni-based crystalline materials $[17,18]$. Also, the Ni-B films showed higher electrocatalytic activity for methanol oxidation than $\mathrm{Pt} / \mathrm{C}$ electrodes [19]. Evidently, these reports have demonstrated that amorphous Ni-based catalysts are promising non-noble metal alternatives for sustainable electrocatalysis. Amorphous Ni-based catalysts with highly ordered $\mathrm{TiO}_{2}$ nanotube arrays and a nanoporous $\mathrm{Cu}$ substrate have also been developed as a strategy for improving the catalytic activity of these materials $[6,20]$. Furthermore, doping amorphous Ni-based materials with a third element, such as $\mathrm{Cu}$ or $\mathrm{O}$, has been shown to improve the catalytic activity via synergistic effects [21,22].

In comparison to crystalline materials, studies investigating the electrocatalytic oxidation of methanol using amorphous Ni-based catalysts have lacked comprehensive details. These reports have mainly focused on improving the catalytic performance of these species based on the influence of substrates and doping elements, but failed to thoroughly probe the inherent electrocatalytic reaction mechanism. Our previous work and most literature reports have indicated that methanol is oxidized by $\mathrm{NiOOH}$ produced on Ni-based catalysts [23]. As early as 1972, Fleischmann et al. proposed that the oxidation of $\mathrm{Ni}(\mathrm{OH})_{2}$ to $\mathrm{NiOOH}$ was faster than methanol oxidation by $\mathrm{NiOOH}$ on $\mathrm{Ni}$-based materials [8].

$$
\begin{gathered}
\mathrm{Ni}(\mathrm{OH})_{2}+\mathrm{OH}^{-} \stackrel{\text { fast }}{\rightarrow} \mathrm{NiOOH}+\mathrm{H}_{2} \mathrm{O}+\mathrm{e}^{-} \\
\mathrm{NiOOH}+\text { methanol } \stackrel{\text { slow }}{\rightarrow} \mathrm{Ni}(\mathrm{OH})_{2}+\text { products }
\end{gathered}
$$

Despite these theories, few researchers have proposed more detailed electrocatalytic reaction mechanisms for methanol oxidation on Ni-based catalysts. Hillman et al. suggested that hydroxide ions were the mobile species associated with the redox processes of thin, crystalline $\alpha$ - and $\beta-\mathrm{Ni}(\mathrm{OH})_{2}$ films exposed to aqueous $\mathrm{LiOH}$ solutions [24,25]. Taking into account the limited charge transport through $\mathrm{Ni}(\mathrm{OH})_{2}$ films, Taraszewska and Rosłonek [26] imagined that the methanol molecules, which could penetrate deeper, were oxidized during the positive sweep, and the other methanol molecules were oxidized during the cathodic sweep. Nevertheless, mechanistic understanding of Ni-based crystalline materials during the electrocatalytic oxidation of methanol is lacking, and further work probing these reactions and those catalyzed by amorphous materials is needed.

Given the limited number of studies aimed at improving the performance of these electrocatalytic systems, research on amorphous Ni-based materials is considered to be in its infancy. For example, there has been no report to date investigating the Co doping of typical Ni-B amorphous materials. The excellent catalytic activity of Co [27] inspired our group to study the role of Co in strengthening the electroactivity of amorphous Ni-B-Co nanoparticles toward methanol oxidation [23]. We determined in this previous report that $\mathrm{Co}$ could promote generation of the active $\mathrm{NiOOH}$ species needed to oxidize methanol by preferentially forming $\mathrm{CoOOH}$. In addition, Co doping was also shown to increase the $\mathrm{Ni}$ 
$3 d$ orbital vacancies on the $\mathrm{Ni}-\mathrm{Co}-\mathrm{B}$ nanoparticles and its adsorption of methanol and intermediate species, thus improving catalytic activity. In the present work, the electrocatalytic reaction mechanism of methanol oxidation on amorphous Ni-B and Ni-B-Co nanoparticles in alkaline media are further discussed and analyzed in detail. Herein, we propose the morphological structure and mechanism of electrochemical catalysis on the surface of amorphous Ni-B and Ni-B-Co nanoparticles for methanol oxidation. We anticipate that these findings will lay the foundation for developing other amorphous Ni-based electrocatalysts for sustainable energy conversion applications.

\section{Results}

\subsection{Physical Characterizations}

The chemical components of the Ni-B and Ni-Co-B nanoparticles were detected by ICP, which essentially corresponded to the $\mathrm{Co}^{2+} / \mathrm{Ni}^{2+}$ molar ratios of the reaction reagents. The $\mathrm{X}$-ray diffraction patterns of the Ni-B and Ni-B-Co nanoparticles are displayed in Figure S1. A broad diffraction peak around $2 \theta\left(45^{\circ}\right)$ attributed to typical amorphous features [28,29]. The morphologies of the Ni-B and $\mathrm{Ni}$-Co-B nanoparticles were uniformly spherical in the TEM images (Figure 1), and the mean discrete particle sizes were statistically determined to be around $12 \mathrm{~nm}$, as determined by the distribution histogram in Figure S2.
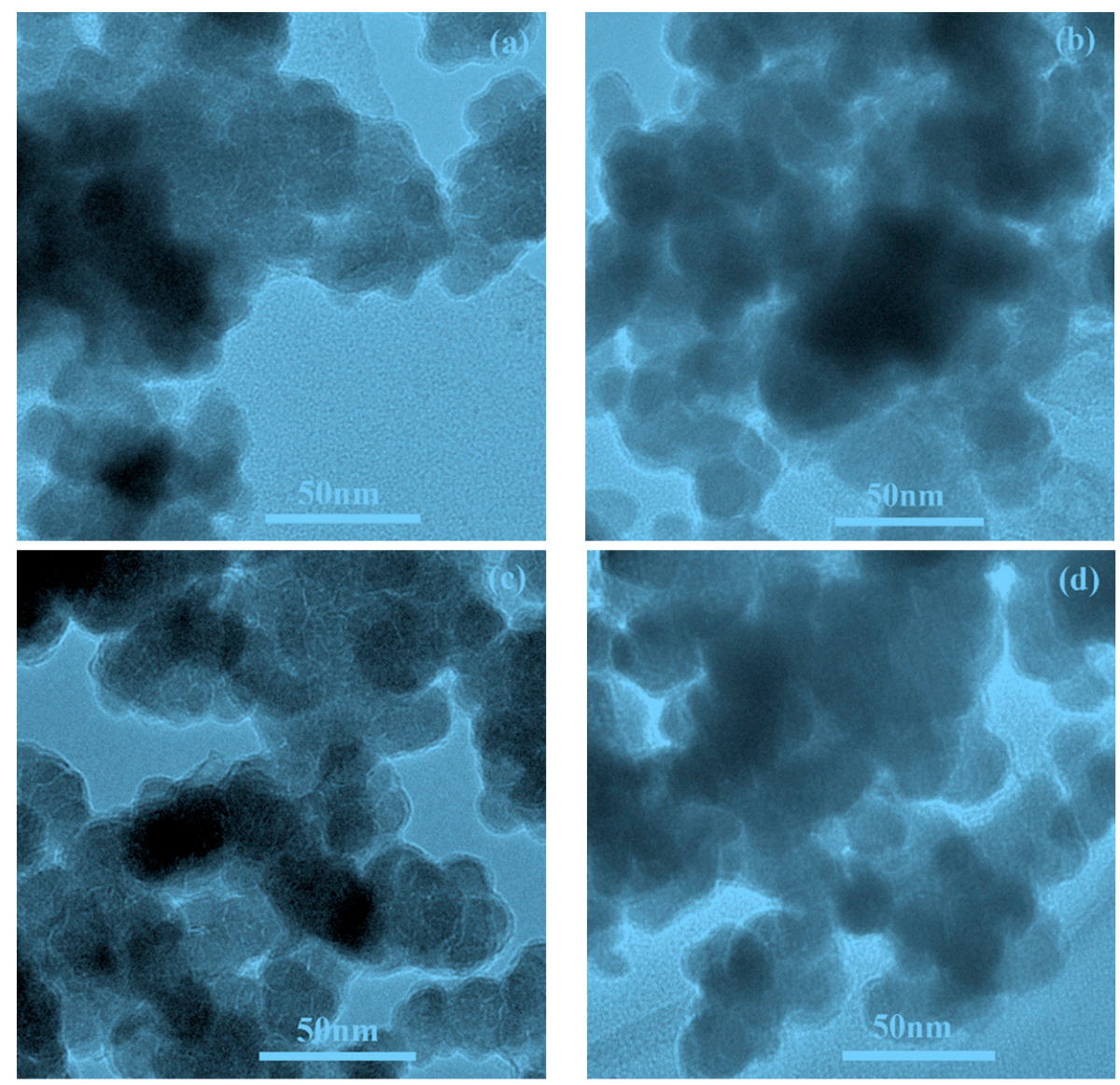

Figure 1. TEM images of (a) Ni-B, (b) Ni-B-Co $\mathrm{Co}_{0.02}$, (c) $\mathrm{Ni}-\mathrm{B}-\mathrm{Co}_{0.05}$, and (d) $\mathrm{Ni}-\mathrm{B}-\mathrm{Co}_{0.1}$ nanoparticles.

Figure S3a,b shows the XPS spectra of Ni $2 p$ and B 1s. The contaminated C 1s peak (binding energy $(B E)=284.8 \mathrm{eV}$ ) was used to calibrate the BE [30-32]. It is clear from Figure S3 that B and Ni were present as both alloyed $\left(\mathrm{B}^{0}\right.$ and $\left.\mathrm{Ni}^{0}\right)$ and oxidized $\left(\mathrm{B}^{3+}\right.$ and $\mathrm{Ni}^{2+}$ ) species in the amorphous $\mathrm{Ni}-\mathrm{B}$ and $\mathrm{Ni}-\mathrm{B}-\mathrm{Co}$ nanoparticles. The $\mathrm{BEs}$ of $\mathrm{Ni}^{0}$ in the amorphous $\mathrm{Ni}-\mathrm{B}, \mathrm{Ni}-\mathrm{B}-\mathrm{Co}_{0.02}, \mathrm{Ni}-\mathrm{B}-\mathrm{Co}_{0.05}$, and $\mathrm{Ni}-\mathrm{B}-\mathrm{Co}_{0.1}$ nanoparticles were $852.60,852.56,852.51$, and $852.16 \mathrm{eV}$, respectively; the BEs of $\mathrm{B}^{0}$ were $188.07,188.07$, 
187.74, and $187.58 \mathrm{eV}$. As the data demonstrate, the BEs of both $\mathrm{B}$ and $\mathrm{Ni}$ in the amorphous Ni-B and Ni-B-Co nanoparticles gradually decreased as the Co content increased. These results indicate that the electrons were partially transferred from $\mathrm{Co}$ to $\mathrm{B}$ and $\mathrm{Ni}$ in the amorphous Ni-B-Co nanoparticles. The Ni atom $\left(3 d^{8} 4 s^{2}\right)$ has more $3 d$ electrons than the Co atom $\left(3 d^{7} 4 s^{2}\right)$. We inferred that some of the $d$ electrons from $\mathrm{Ni}\left(3 d^{8} 4 s^{2}\right)$ transferred to the $d$ electron band of $\mathrm{Co}\left(3 d^{7} 4 s^{2}\right)$ and that the electron cloud of Co shifted toward $\mathrm{Ni}$ as a whole. Thus, the Ni components of the Ni-B-Co nanoparticles carried more negative charge because of the higher electronegativity of Ni. We hypothesized that the transfer of $\mathrm{Ni} d$ electrons to Co could increase the vacancy of $\mathrm{Ni} 3 d$ orbitals, which would improve the adsorption ability of $\mathrm{Ni} 3 d$ toward molecules such as methanol [23]. Moreover, if Co could increase the electron conductivity of nickel hydroxide [33], it could potentially improve the electrocatalytic activity of Ni-B-Co nanoparticles as well.

In comparison to the bulk composition (Table S1), the surface compositions of amorphous Ni-B and Ni-B-Co nanoparticles were more B- and Co-rich. Surface segregation of B and Co components on amorphous Ni-B and Ni-B-Co nanoparticles was also detected in these samples.

The crystallization process of amorphous Ni-B and Ni-B-Co nanoparticles was analyzed by DSC [34]. As shown in Figure 2, four exothermal peaks appeared at $421.1^{\circ} \mathrm{C}(\mathrm{Ni}-\mathrm{B}), 423.1^{\circ} \mathrm{C}\left(\mathrm{Ni}-\mathrm{B}-\mathrm{Co}_{0.02}\right), 428.6^{\circ} \mathrm{C}$ (Ni-B-Co $\left.\mathrm{Co}_{0.05}\right)$, and $433.5^{\circ} \mathrm{C}\left(\mathrm{Ni}-\mathrm{B}-\mathrm{Co}_{0.1}\right)$. These results showed that the crystallization temperatures increased as the Co content increased, which also reveals the higher thermostability of Ni-B-Co javascript:;nanoparticles due to the addition of Co. It can also be speculated that Co serves not only to transfer electrons from $\mathrm{Co}$ to $\mathrm{B}$ and $\mathrm{Ni}$, but also to enhance the binding force of chemical bonds throughout the Ni-B-Co nanoparticles. These synergistic effects provided preliminary evidence that the electrocatalytic activity of amorphous Ni-B-Co nanoparticles could be affected by atom doping. Furthermore, a single exothermic peak on the DSC curve suggested a one-step transformation of the amorphous Ni-B and Ni-B-Co nanoparticles from their amorphous structures to their corresponding crystalline states [35].

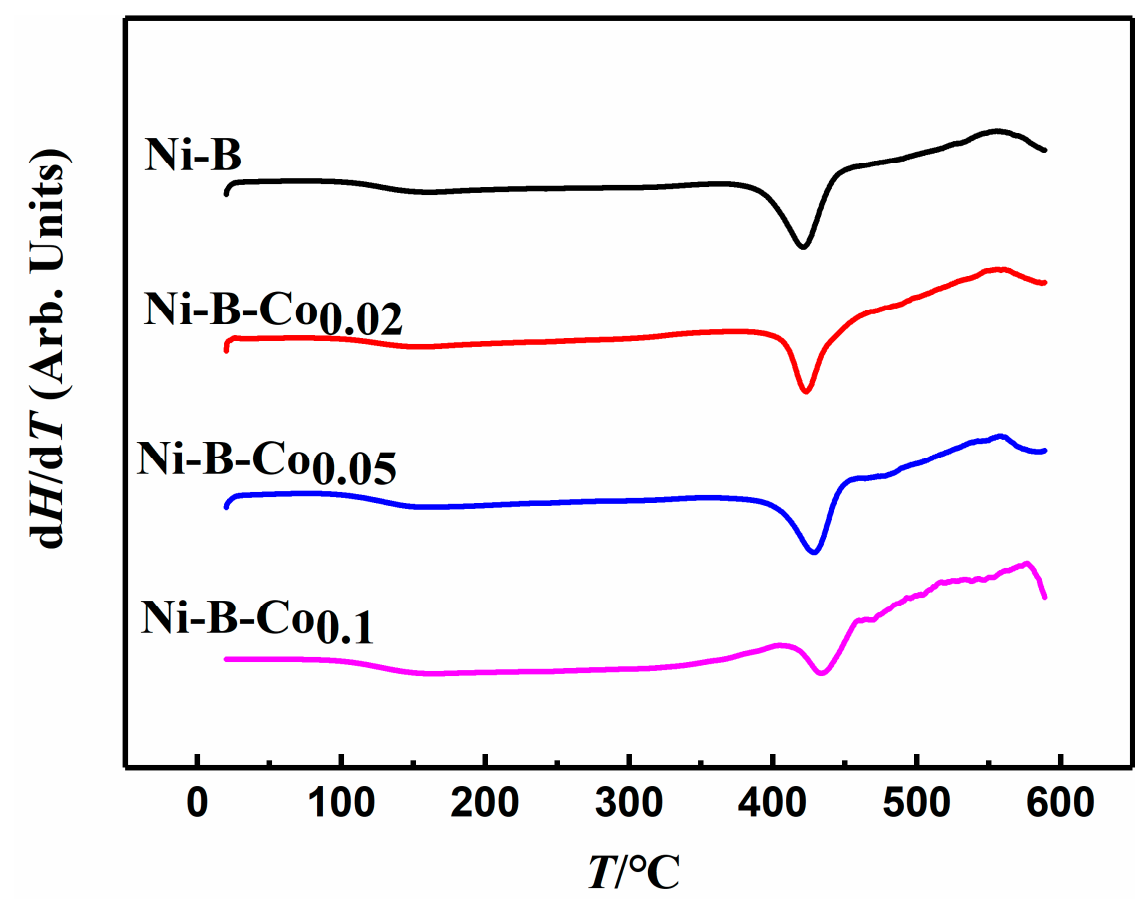

Figure 2. DSC patterns of the Ni-B and Ni-B-Co nanoparticles.

\subsection{Electrochemical Performance}

Figure 3 shows the third-cycle cyclic voltammograms of Ni-B and Ni-B-Co nanoparticles at scan rates between 10 and $100 \mathrm{mV} \mathrm{s}^{-1}$ and potentials ranging from 0.0 to $0.8 \mathrm{~V}$ in $1.0 \mathrm{M} \mathrm{NaOH}$ solution. 
The depicted insets are the corresponding linear dependencies of the cathodic and anodic peak current densities versus the square roots of the scan rates. A pair of redox peaks was observed around 0.4 and $0.3 \mathrm{~V}$ in Figure 3 before the oxygen evolution peak, which corresponds to the $\mathrm{NiOOH} / \mathrm{Ni}(\mathrm{OH})_{2}$ redox couple in Equation (1) [36].
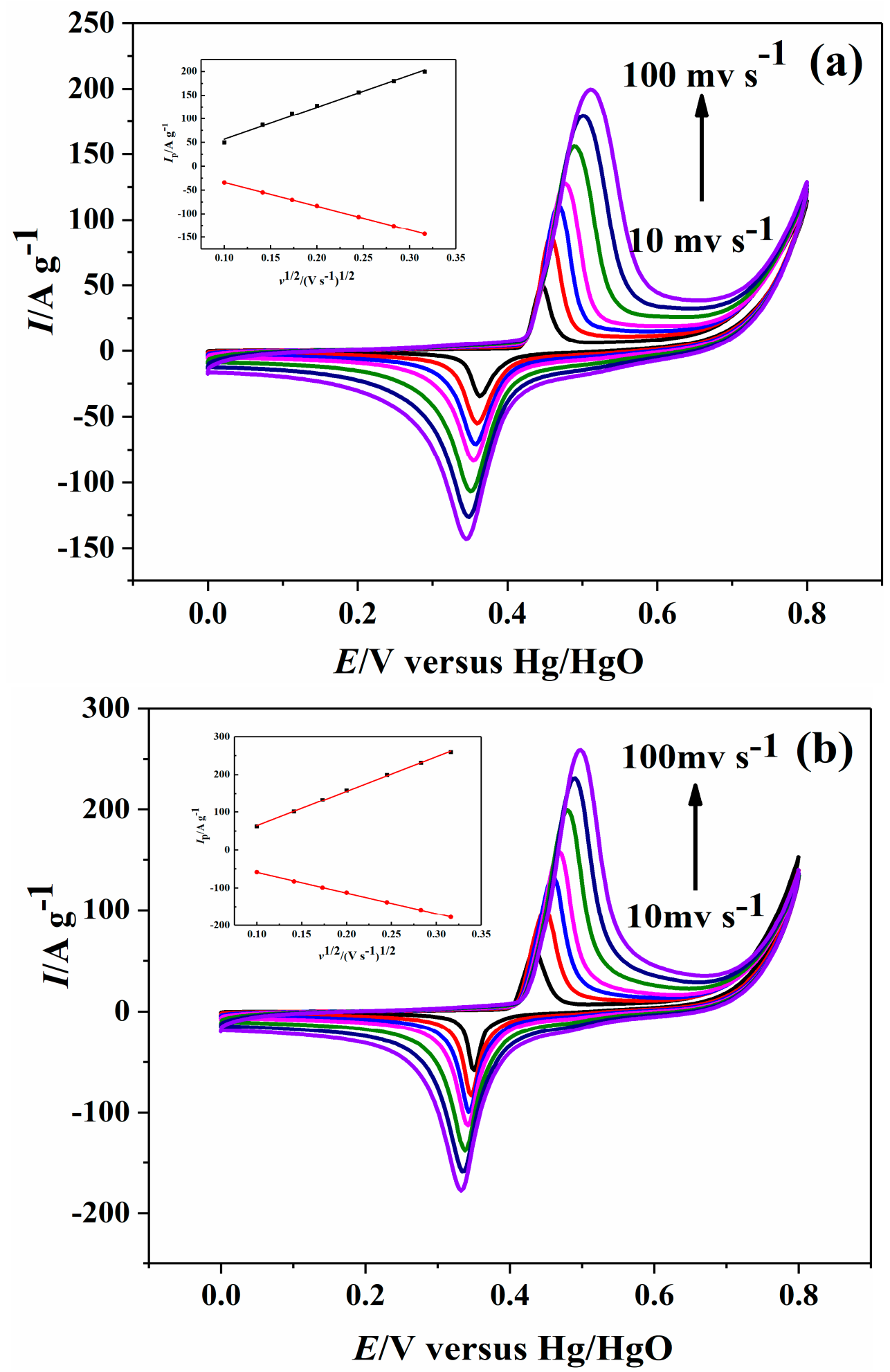

Figure 3. Cont. 

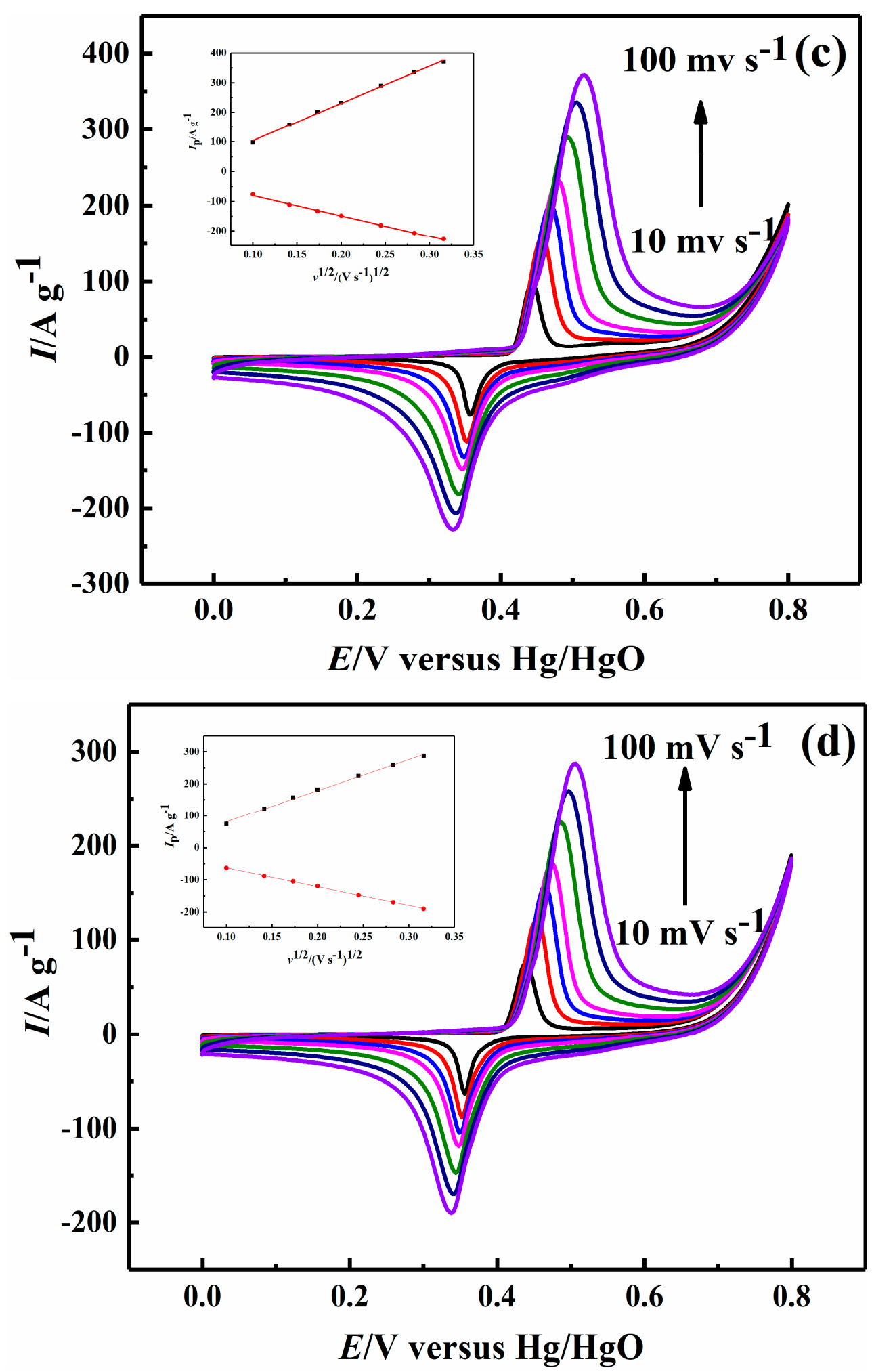

Figure 3. Cyclic voltammograms of $\mathrm{Ni}-\mathrm{B}(\mathbf{a}), \mathrm{Ni}-\mathrm{B}-\mathrm{Co}_{0.02}(\mathbf{b}), \mathrm{Ni}-\mathrm{B}-\mathrm{Co}_{0.05}$ (c), and $\mathrm{Ni}-\mathrm{B}-\mathrm{Co}_{0.1}$ (d) nanoparticles at potentials ranging from 0.0 to $0.8 \mathrm{~V}$ at scan rates of $10,20,30,40,60,80$, and $100 \mathrm{mV} \mathrm{s}^{-1}$ in $1 \mathrm{M} \mathrm{NaOH}$ solution. Insets: Linear dependency of the corresponding cathodic and anodic peak currents as a function of the square roots of the scan rates.

From Figure 1 and Table 1 the anodic and cathodic peak currents for the Ni-B and Ni-B-Co nanoparticles increased with increasing scan rates. And as the Co content increased, the anodic and 
cathodic peak currents initially increased and then decreased. At the same time, the anodic peak potentials exhibited a positive shift, whereas the cathodic peak potentials experienced a negative shift. The peak currents were proportional to the square root of the scan rates $\left(v^{1 / 2}\right)$, demonstrating a diffusion-controlled process [18]. The diffusion coefficient $\left(D_{\mathrm{o}}\right)$ of the rate-limiting hydroxyl ion was obtained from the classical Randles-Sevcik equation as follows:

$$
I_{\mathrm{p}}=2.69 \times 10^{5} n^{3 / 2} A D_{0}^{1 / 2} v^{1 / 2} C_{0}
$$

where $n$ is the number of electrons transferred, $A$ is the apparent surface area of the electrode $\left(\mathrm{cm}^{2}\right)$, $D_{0}$ is the diffusion coefficient of the rate-limiting hydroxyl ion $\left(\mathrm{cm}^{2} \mathrm{~s}^{-1}\right)$, and $C_{0}$ is the hydroxyl ion concentration $\left(\mathrm{mol} \mathrm{cm}^{-3}\right)$. The $D_{0}$ for Ni-B, Ni-B-Co $\mathrm{Co}_{0.02}, \mathrm{Ni}-\mathrm{B}-\mathrm{Co}_{0.05}$, and Ni-B-Co $\mathrm{Co}_{0.1}$ were calculated to be $1.28 \times 10^{-9}, 2.35 \times 10^{-9}, 4.48 \times 10^{-9}$ and $2.67 \times 10^{-9} \mathrm{~cm}^{2} \mathrm{~s}^{-1}$, respectively. That is to say, the $D_{0}$ ratios (with respect to Ni-B) for Ni-B-Co ${ }_{0.02}, \mathrm{Ni}-\mathrm{B}-\mathrm{Co}_{0.05}$, and $\mathrm{Ni}-\mathrm{B}-\mathrm{Co}_{0.1}$ were determined to be $1.83,3.50$, and 2.09, respectively. As the Co content increased, the diffusion coefficients of the Ni-B-Co nanoparticles initially increased before decreasing at higher Co concentrations. These data provide evidence for Co increasing the diffusion rate of hydroxyl ions.

Table 1. The $\mathrm{NiOOH} / \mathrm{Ni}(\mathrm{OH})_{2}$ oxidation (left) and reduction (right) peak currents $\left(\mathrm{A} \mathrm{g}^{-1}\right)$ on $\mathrm{Ni}-\mathrm{B}$ and Ni-B-Co nanoparticles.

\begin{tabular}{ccccc}
\hline Sample & Ni-B & Ni-B-Co.02 & Ni-B-Co.05 & Ni-B-Co.1 $_{\mathbf{0}}$ \\
\hline $10 \mathrm{mV} \mathrm{s}^{-1}$ & $49.98,-34.37$ & $61.76,-58.38$ & $97.33,-76.42$ & $74.29,-63.12$ \\
$20 \mathrm{mV} \mathrm{s}^{-1}$ & $86.89,-55.09$ & $101.12,-83.09$ & $158.27,-111.66$ & $122.54,-87.94$ \\
$30 \mathrm{mV} \mathrm{s}^{-1}$ & $111.01,-70.68$ & $132.91,-99.54$ & $200.53,-133.18$ & $157.82,-104.20$ \\
$40 \mathrm{mV} \mathrm{s}^{-1}$ & $127.64,-83.52$ & $158.21,-112.60$ & $232.52,-148.67$ & $182.08,-119.08$ \\
$60 \mathrm{mV} \mathrm{s}^{-1}$ & $155.94,-106.84$ & $199.21,-138.24$ & $289.39,-181.61$ & $225.22,-147.34$ \\
$80 \mathrm{mV} \mathrm{s}^{-1}$ & $179.41,-126.28$ & $231.28,-158.80$ & $335.77,-206.66$ & $258.44,-169.62$ \\
$100 \mathrm{mV} \mathrm{s}^{-1}$ & $199.47,-143.13$ & $259.25,-177.9$ & $371.84,-228.04$ & $287.28,-189.79$ \\
\hline
\end{tabular}

\subsection{Effect of Methanol Concentration on Electrocatalytic Properties}

Figure 4 shows the cyclic voltammograms of $\mathrm{Ni}-\mathrm{B}$ and Ni-B-Co nanoparticles in $1.0 \mathrm{M} \mathrm{NaOH}$ solutions with methanol concentrations ranging from 0.1 to $1.5 \mathrm{M}$ at a scan rate of $10 \mathrm{mV} \mathrm{s}^{-1}$. Tables 2 and 3 provide the methanol oxidation peak currents and the reduction peak currents of $\mathrm{NiOOH} / \mathrm{Ni}(\mathrm{OH})_{2}$ on the $\mathrm{Ni}-\mathrm{B}$ and $\mathrm{Ni}-\mathrm{B}-\mathrm{Co}$ nanoparticles, respectively. When the methanol concentration was relatively low at 0.1 and $0.2 \mathrm{M}$, the oxidation peaks of $\mathrm{Ni}(\mathrm{OH})_{2} / \mathrm{NiOOH}$ at $0.45 \mathrm{~V}$ (i.e., before the methanol oxidation peaks) were observed (Figure 4). However, these $\mathrm{Ni}(\mathrm{OH})_{2} / \mathrm{NiOOH}$ oxidation peaks disappeared when the methanol concentration was greater than or equal to $0.5 \mathrm{M}$. The methanol oxidation peak currents for both the Ni-B and Ni-B-Co nanoparticles during methanol oxidations continually increased as the methanol concentration increased, as shown in Figure 4 and Table 2. However, the methanol oxidation peak currents decreased when the methanol concentration reached $1.5 \mathrm{M}$. In addition, as the Co content increased, the methanol oxidation currents at different methanol concentrations initially increased and then decreased, achieving a maximum value and best catalytic activity with the $\mathrm{Ni}-\mathrm{B}-\mathrm{Co}_{0.05}$ nanoparticles. These results also implied that $\mathrm{Ni}$ was still the main catalyst in the methanol oxidation reaction, whereas $\mathrm{Co}$ only played an auxiliary role by promoting $\mathrm{NiOOH}$ production and increasing the absorption ability of the $\mathrm{Ni} 3 d$ orbital toward methanol and intermediate species.

A double logarithmic plot of peak current versus methanol concentration is shown in Figure 4 (insets) from 0.1 to $1.0 \mathrm{M}$. The slopes of the curves are equal to the reaction orders with respect to the methanol concentration and were determined to be $0.51,0.51,0.57$, and 0.45 for $\mathrm{Ni}-\mathrm{B}, \mathrm{Ni}-\mathrm{B}-\mathrm{Co}_{0.02}$, $\mathrm{Ni}-\mathrm{B}-\mathrm{Co}_{0.05}$, and $\mathrm{Ni}-\mathrm{B}-\mathrm{Co}_{0.1}$ nanoparticle, respectively. The fractional reaction orders denoted that the rate-determining step involved an adsorbed species generated during the methanol oxidation reaction [37]. In other words, the methanol was first adsorbed onto the surface of Ni-B and Ni-B-Co nanoparticles and then oxidized by $\mathrm{NiOOH}$ [38]. 

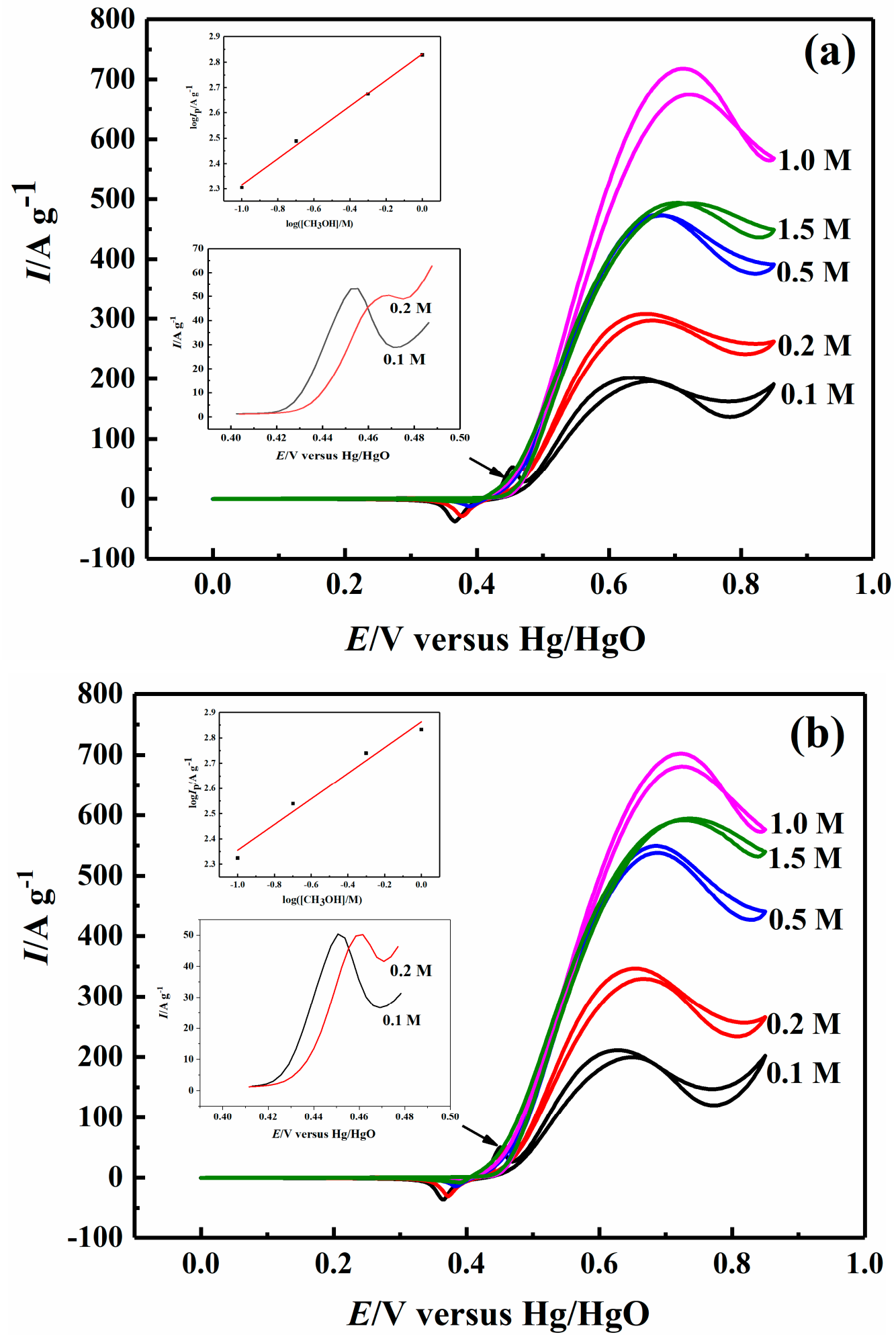

Figure 4. Cont. 

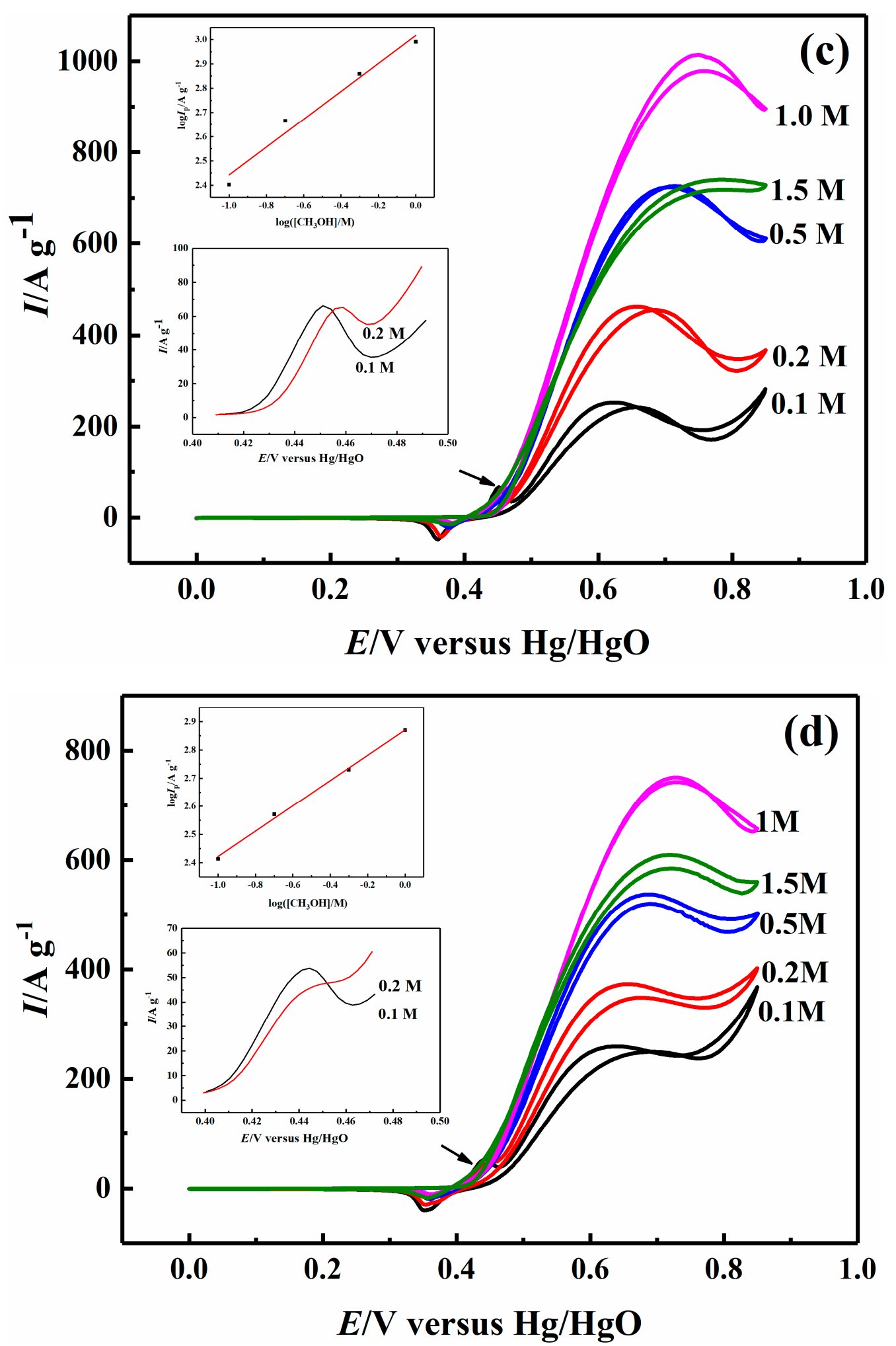

Figure 4. Cyclic voltammograms of the methanol oxidation on $\mathrm{Ni}-\mathrm{B}(\mathbf{a}), \mathrm{Ni}-\mathrm{B}-\mathrm{Co}_{0.02}(\mathbf{b}), \mathrm{Ni}-\mathrm{B}-\mathrm{Co}_{0.05}$ (c), and $\mathrm{Ni}-\mathrm{B}-\mathrm{Co}_{0.1}$ (d) nanoparticles at potentials ranging from 0 to $0.8 \mathrm{~V}$ in $1.0 \mathrm{M} \mathrm{NaOH} /(0.1-1.5 \mathrm{M})$ $\mathrm{CH}_{3} \mathrm{OH}$ solutions at a scan rate of $10 \mathrm{mV} \mathrm{s}^{-1}$. Insets: Double logarithmic plots of the anodic peak currents for methanol oxidation versus methanol concentrations. 
Table 2. The $\mathrm{CH}_{3} \mathrm{OH}$ oxidation peak currents $\left(\mathrm{A} \mathrm{g}^{-1}\right)$ on Ni-B and Ni-B-Co nanoparticles.

\begin{tabular}{ccccc}
\hline Sample & Ni-B & Ni-B-Co $\mathbf{C o}_{\mathbf{0 2}}$ & Ni-B-Co.05 $_{0.1}$ & Ni-B-Co $_{\mathbf{0 . 1}}$ \\
\hline $0.1 \mathrm{M} \mathrm{CH}_{3} \mathrm{OH}$ & 203.03 & 211.05 & 254.84 & 259.22 \\
$0.2 \mathrm{M} \mathrm{CH}_{3} \mathrm{OH}$ & 305.39 & 346.50 & 464.11 & 373.31 \\
$0.5 \mathrm{M} \mathrm{CH}_{3} \mathrm{OH}$ & 472.96 & 549.50 & 723.37 & 537.31 \\
$1 \mathrm{M} \mathrm{CH}_{3} \mathrm{OH}$ & 673.94 & 680.87 & 978.49 & 742.65 \\
$1.5 \mathrm{M} \mathrm{CH}_{3} \mathrm{OH}$ & 494.19 & 594.73 & 740.13 & 609.44 \\
\hline
\end{tabular}

Table 3. The reduction peak currents $\left(\mathrm{A} \mathrm{g}^{-1}\right)$ on Ni-B and Ni-B-Co nanoparticles.

\begin{tabular}{ccccc}
\hline Sample & Ni-B & Ni-B-Co. $_{\mathbf{0 . 2}}$ & Ni-B-Co.05 $_{0.1}$ & Ni-B-Co $_{\mathbf{0 . 1}}$ \\
\hline $1.0 \mathrm{M} \mathrm{NaOH}$ & 34.36 & 58.38 & 76.42 & 63.12 \\
$0.1 \mathrm{M} \mathrm{CH}_{3} \mathrm{OH}$ & 37.93 & 35.87 & 47.52 & 39.12 \\
$0.2 \mathrm{M} \mathrm{CH}_{3} \mathrm{OH}$ & 28.76 & 30.48 & 41.34 & 29.28 \\
$0.5 \mathrm{M} \mathrm{CH}_{3} \mathrm{OH}$ & 12.64 & 14.18 & 22.03 & 18.80 \\
$1 \mathrm{M} \mathrm{CH}_{3} \mathrm{OH}$ & 2.05 & 6.34 & 11.52 & 10.27 \\
$1.5 \mathrm{M} \mathrm{CH}_{3} \mathrm{OH}$ & 4.77 & 8.00 & 14.76 & 16.60 \\
\hline
\end{tabular}

Table 3 summarizes the reduction peak currents of $\mathrm{NiOOH}$ on $\mathrm{Ni}-\mathrm{B}$ and $\mathrm{Ni}-\mathrm{B}-\mathrm{Co}$ nanoparticles that initially decreased and then increased with increasing methanol concentration (0-1.5 M). At different methanol concentrations (0-1.0 M), the reduction peak currents of $\mathrm{NiOOH}$ initially increased and then decreased as the Co content increased. In addition, the onset potentials of $\mathrm{NiOOH}$ reduction on Ni-B and Ni-B-Co nanoparticles shifted in the negative direction as the methanol concentration $(0-1.0 \mathrm{M})$ increased.

\subsection{Effect of Sodium Hydroxide Concentration on Electrocatalytic Properties}

The $\mathrm{CV}$ experiments were also carried out (Figure 5) using $1.0 \mathrm{M} \mathrm{CH}_{3} \mathrm{OH}$ in $0.5-2.0 \mathrm{M} \mathrm{NaOH}$ to determine the reaction order of $\mathrm{NaOH}$. The methanol oxidation currents on the $\mathrm{Ni}-\mathrm{B}$ and $\mathrm{Ni}-\mathrm{B}-\mathrm{Co}$ nanoparticles increased as the $\mathrm{NaOH}$ concentration increased. The anodic onset and peak potentials were shifted to more negative values as the concentration of $\mathrm{NaOH}$ increased, which meant that the reaction kinetics of methanol oxidation were improved due to the greater availability of $\mathrm{OH}^{-}$ in the solution and/or higher $\mathrm{OH}^{-}$coverage on the surface of Ni-B and Ni-B-Co nanoparticles [39]. The reaction order values with respect to the $\mathrm{OH}^{-}$concentration on the Ni-B, Ni-B-Co $\mathrm{Co}_{0.02}, \mathrm{Ni}-\mathrm{B}-\mathrm{Co}_{0.05}$, and Ni-B-Co $\mathrm{O}_{0.1}$ nanoparticles were calculated to be $0.92,0.81,0.89$, and 0.84 , respectively, indicating a near to first-order reaction for $\mathrm{OH}^{-}$during the methanol oxidation (Figure 5, insets). These values simultaneously signify that, similar to the methanol molecules, the hydroxide ion was first adsorbed as a reactant on the surface of the Ni-B and Ni-B-Co nanoparticles, and then the adsorbed $\mathrm{OH}^{-}\left(\mathrm{or}\left(\mathrm{OH}^{-}\right)_{\text {ads }}\right)$ was involved in the generation of $\mathrm{NiOOH}$. Since the reaction order of $\mathrm{OH}^{-}$was significantly higher than the reaction order of methanol, the adsorption rate of $\mathrm{OH}^{-}$was relatively slow, affecting the overall reaction rate of methanol oxidation. Moreover, the addition of Co was shown to reduce the reaction order of $\mathrm{OH}^{-}$, indicating that doping Co could increase the adsorption rate of $\mathrm{OH}^{-}$by the catalyst and promote the generation of $\mathrm{NiOOH}$. All of these factors would, in turn, enhance the methanol oxidation process via the reduction of $\mathrm{NiOOH}$. These results demonstrate the crucial role of $\mathrm{OH}^{-}$in the overall process of the methanol oxidation reaction.

The reduction peaks of $\mathrm{NiOOH}$ to $\mathrm{Ni}(\mathrm{OH})_{2}$ were not observed when the $\mathrm{NaOH}$ concentrations were relatively low at 0.5 and $0.75 \mathrm{M}$ for the Ni-B nanoparticles, but the reduction peak currents gradually became apparent starting from $1.0 \mathrm{M}$. In contrast, the reduction peaks of $\mathrm{NiOOH}$ to $\mathrm{Ni}(\mathrm{OH})_{2}$ were already apparent at $0.5 \mathrm{M}$ for the Ni-B-Co nanoparticles. Furthermore, the reduction peak currents of $\mathrm{NiOOH}$ to $\mathrm{Ni}(\mathrm{OH})_{2}$ for the $\mathrm{Ni}-\mathrm{B} / \mathrm{Ni}-\mathrm{B}-\mathrm{Co}$ nanoparticles gradually increased as the $\mathrm{NaOH}$ concentration increased. As the $\mathrm{OH}^{-}$concentration increased and more ions were adsorbed onto 
the surface of the Ni-B and Ni-B-Co nanoparticles, more $\mathrm{NiOOH}$ was generated and retained in the cathodic sweep, although more $\mathrm{NiOOH}$ reacted with methanol in the anodic sweep.
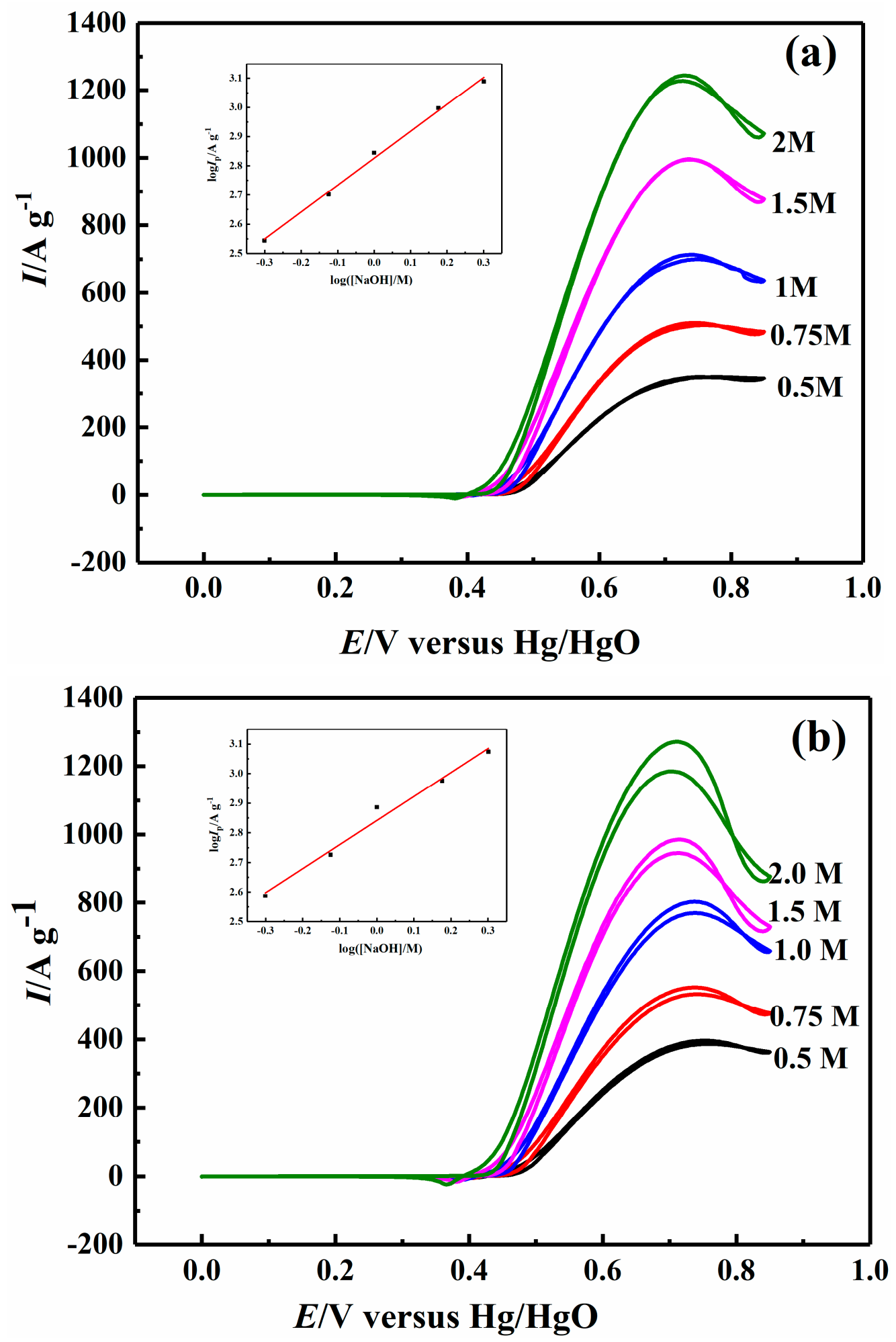

Figure 5. Cont. 

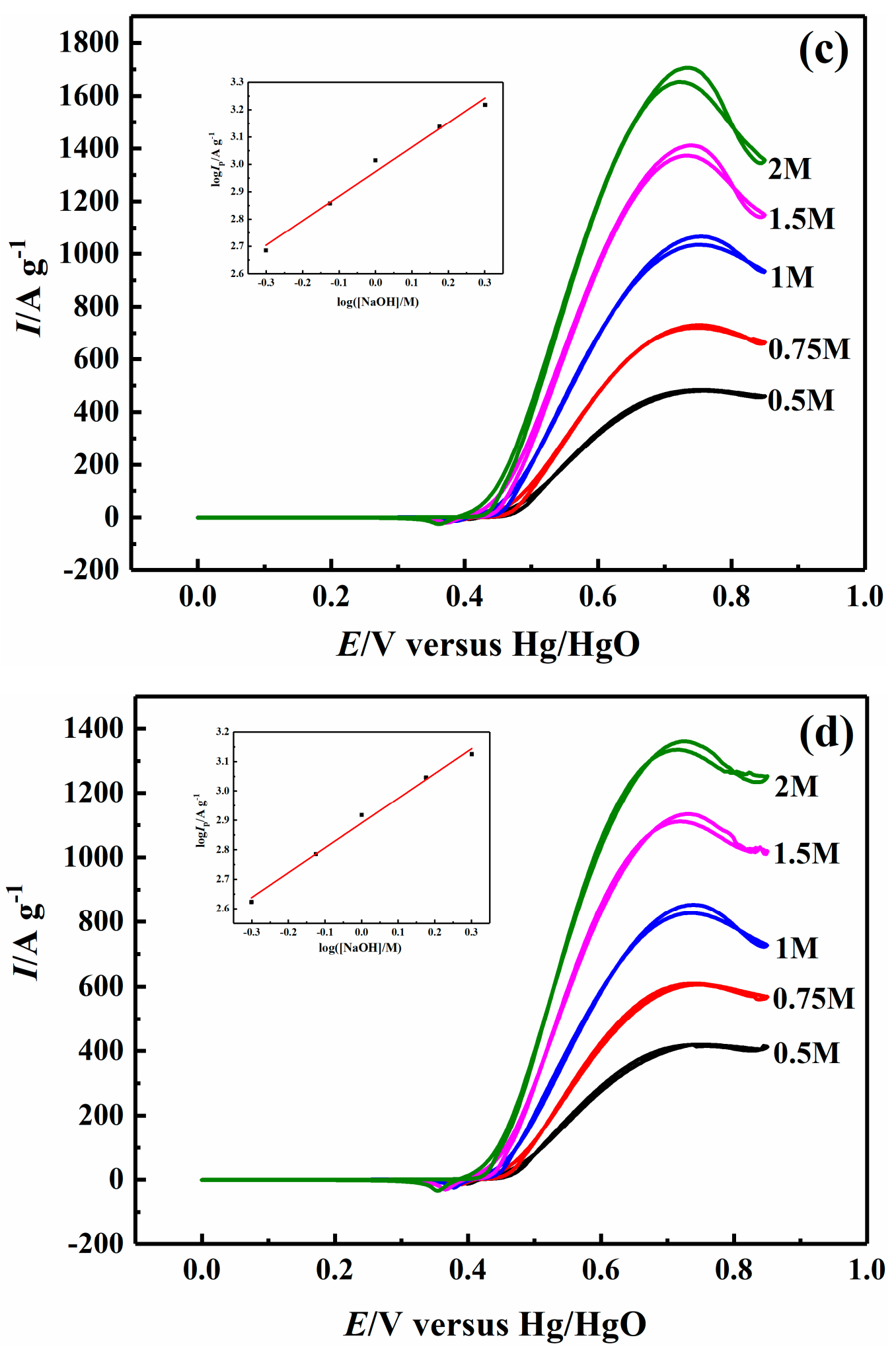

Figure 5. Cont. 

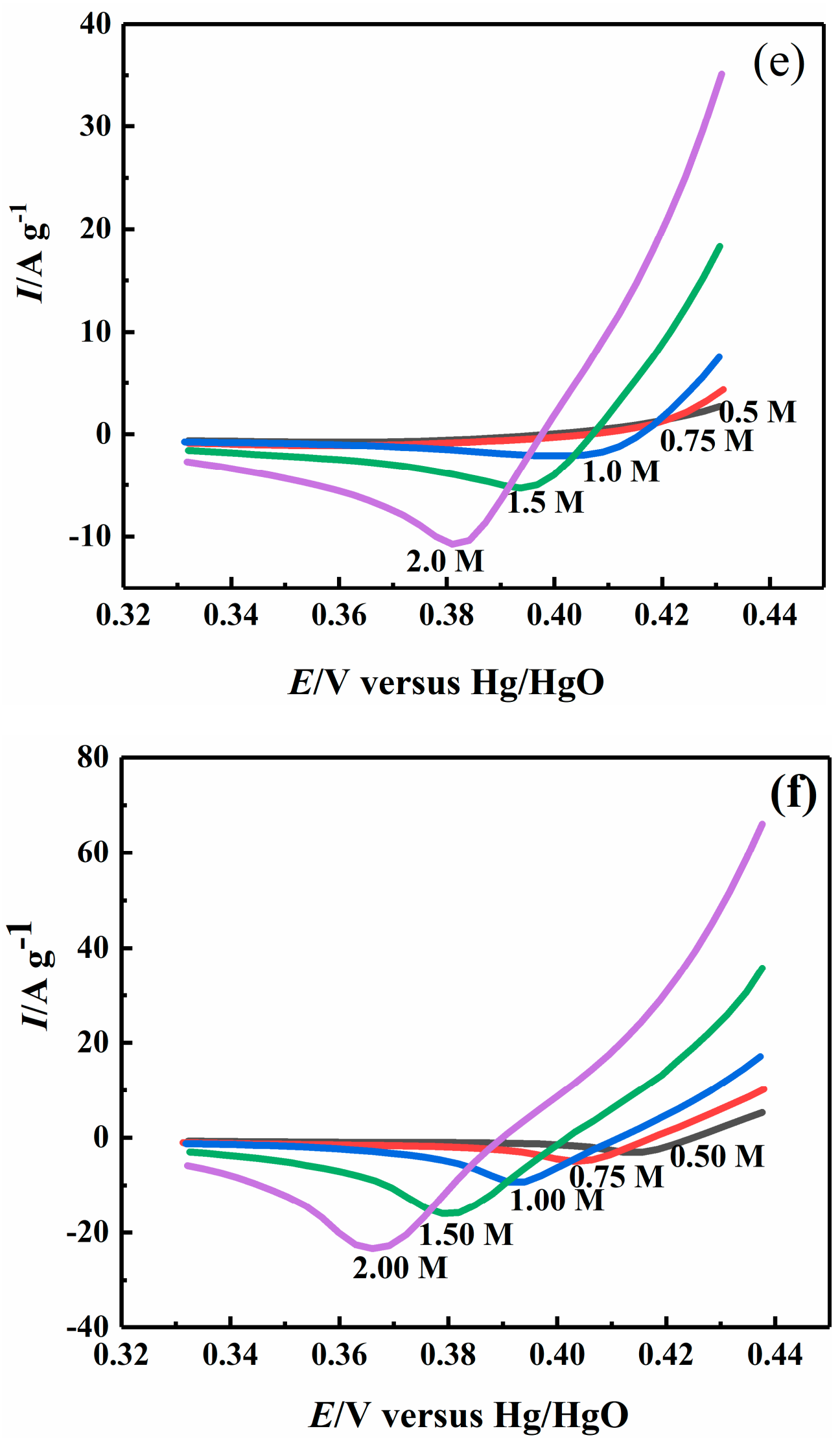

Figure 5. Cont. 

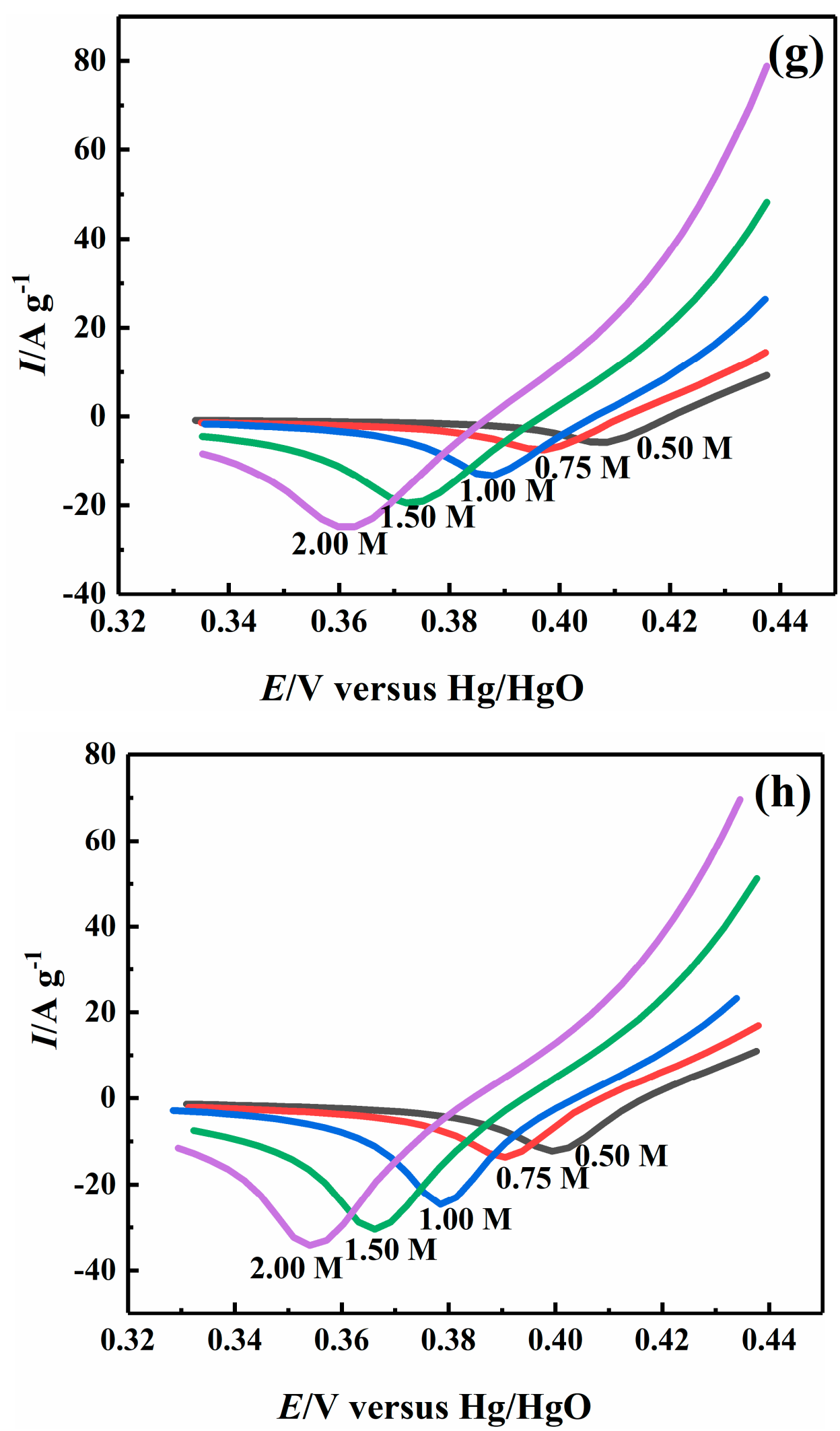

Figure 5. Cyclic voltammograms of the methanol oxidation on $\mathrm{Ni}-\mathrm{B}(\mathbf{a}), \mathrm{Ni}-\mathrm{B}-\mathrm{Co}_{0.02}(\mathbf{b}), \mathrm{Ni}-\mathrm{B}-\mathrm{Co}_{0.05}$ (c), and $\mathrm{Ni}-\mathrm{B}-\mathrm{Co}_{0.1}$ (d) nanoparticles at potentials ranging from 0 to $0.85 \mathrm{~V}$ in $(0.5-2.0 \mathrm{M}) \mathrm{NaOH}+$ $1 \mathrm{M} \mathrm{CH}_{3} \mathrm{OH}$ solutions at a scan rate of $10 \mathrm{mV} \mathrm{s}^{-1}$. Insets: Double logarithmic plots of the anodic peak currents for methanol oxidation versus hydroxide ion concentrations. The reduction peak curves of $\mathrm{NiOOH}$ to $\mathrm{Ni}(\mathrm{OH})_{2}$ are also shown for $\mathrm{Ni}-\mathrm{B}(\mathbf{e}), \mathrm{Ni}-\mathrm{B}-\mathrm{Co}_{0.02}(\mathbf{f}), \mathrm{Ni}-\mathrm{B}-\mathrm{Co}_{0.05}(\mathrm{~g})$, and $\mathrm{Ni}-\mathrm{B}-\mathrm{Co}_{0.1}$ (h) nanoparticles. 


\subsection{Effect of Temperature on Electrocatalytic Properties}

Activation energy parameters are useful for assessing the electrooxidation activity of catalysts. Figure 6 shows the cyclic voltammograms of the methanol oxidation process on the Ni-B and Ni-B-Co nanoparticles from 0 to $0.85 \mathrm{~V}$ between $303.15 \mathrm{~K}$ and $343.15 \mathrm{~K}$ in $1.0 \mathrm{M} \mathrm{NaOH} / 1.0 \mathrm{M} \mathrm{CH}_{3} \mathrm{OH}$ solutions. The insets depict the Arrhenius plots of the reaction at different potentials. The electrode potential of the reference electrode had to be corrected at each temperature, since this value is temperature dependent. For a thermally activated process, the oxidation current of the Ni-B and Ni-B-Co nanoparticles would increase with increasing temperature. The values of the apparent activation energy for methanol oxidation were obtained according to the Arrhenius law [40] as follows:

$$
\log I=\log A-\frac{E_{a}}{2.3 R}\left(\frac{1}{T}\right)
$$

where $E_{\mathrm{a}}$ is the activation energy of the reaction $\left(\mathrm{kJ} \mathrm{mol}^{-1}\right)$ and $A$ is the pre-exponential constant. The calculated $E_{\mathrm{a}}$ values for methanol oxidation (Figure 6) on the Ni-B and Ni-B-Co nanoparticles at different potentials are provided in Table 4 . The $E_{\mathrm{a}}$ of methanol oxidation on Ni-B and Ni-B-Co nanoparticles decreased at $0.50-0.70 \mathrm{~V}$ as the Co content increased. The $E_{\mathrm{a}}$ continued to gradually decreased as the potentials $(0.50-0.70 \mathrm{~V})$ increased further. The element cobalt Co was shown to improve the catalytic activity of the Ni-B-Co nanoparticles for methanol oxidation by decreasing the activation energy of the reaction. At the same time, the detected changes in $E_{\mathrm{a}}$ for methanol oxidation on the Ni-B and Ni-B-Co nanoparticles were similar to the previously reported Pt-based catalysts in alkaline media [41].

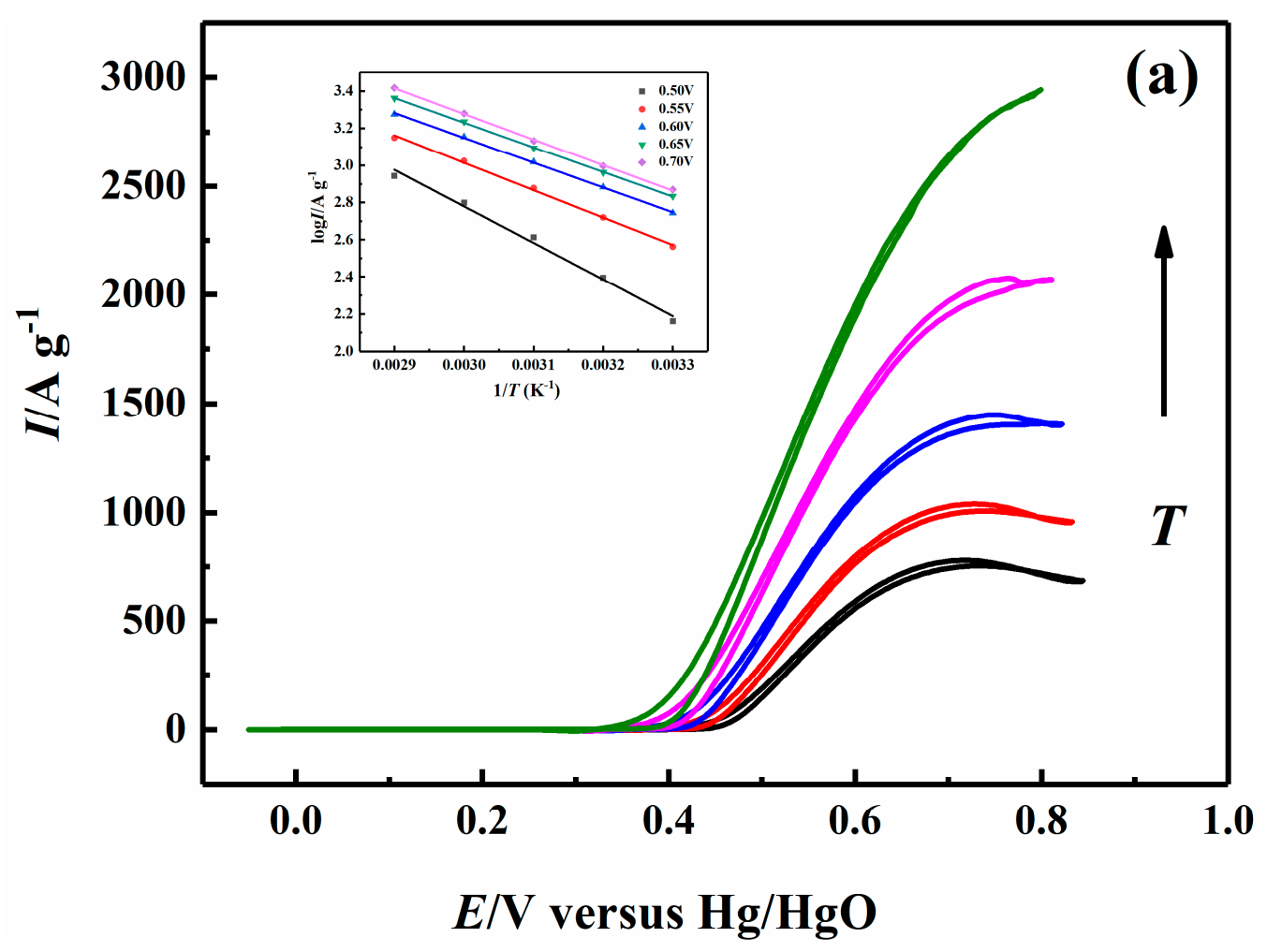

Figure 6. Cont. 

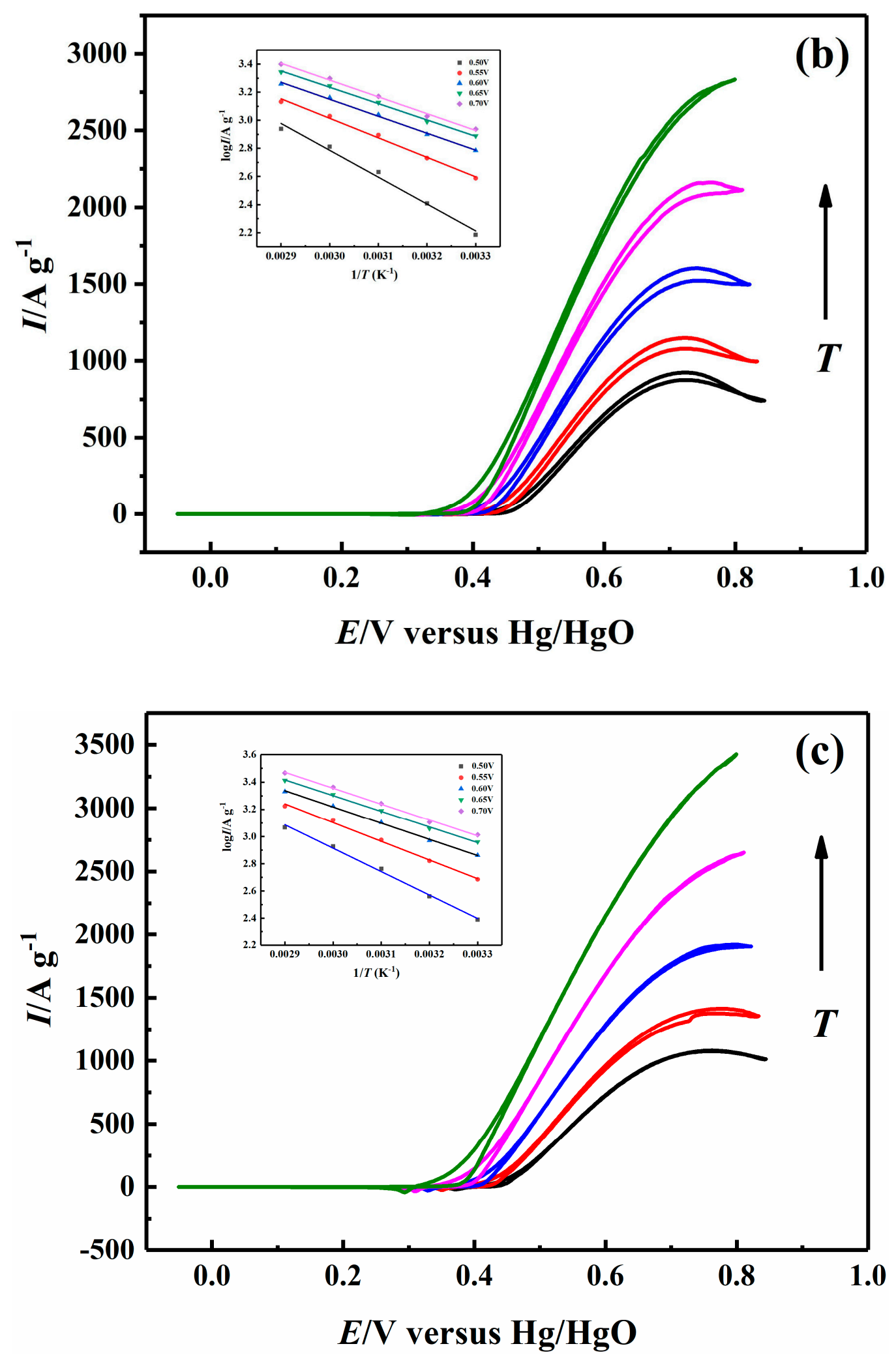

Figure 6. Cont. 


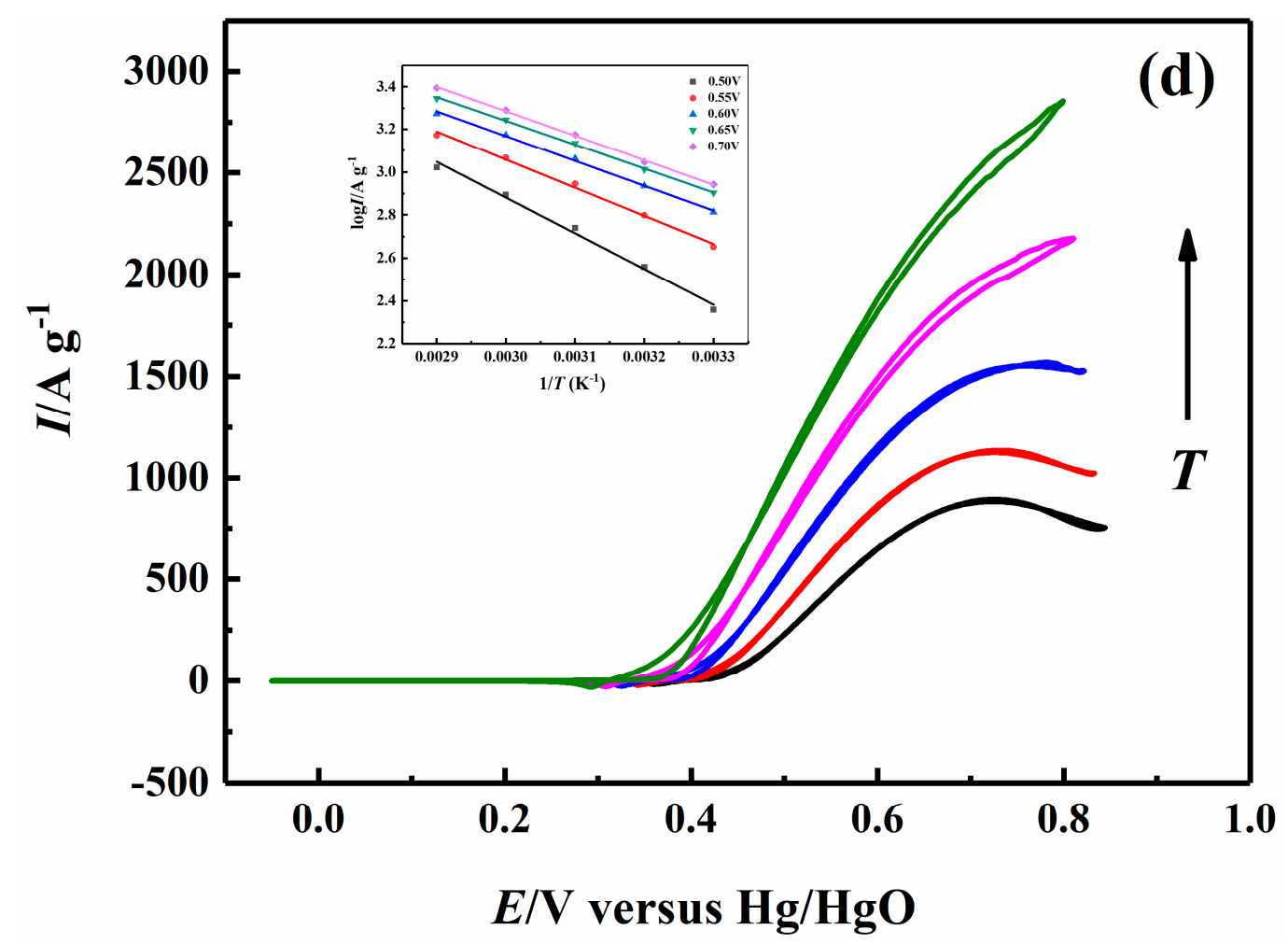

Figure 6. Cyclic voltammograms of the methanol oxidation on $\mathrm{Ni}-\mathrm{B}(\mathrm{a}), \mathrm{Ni}-\mathrm{B}-\mathrm{Co}_{0.02}(\mathbf{b}), \mathrm{Ni}-\mathrm{B}-\mathrm{Co}_{0.05}$ (c), and $\mathrm{Ni}-\mathrm{B}-\mathrm{Co}_{0.1}(\mathrm{~d})$ nanoparticles in a range from 0.0 to $0.85 \mathrm{~V}$ at different temperatures in $1.0 \mathrm{M}$ $\mathrm{NaOH}+1.0 \mathrm{M} \mathrm{CH}_{3} \mathrm{OH}$ solution. Inset: Arrhenius plots of the methanol oxidation on the Ni-B and $\mathrm{Ni}-\mathrm{B}-\mathrm{Co}$ nanoparticles at different potentials.

Table 4. The $E_{\mathrm{a}}\left(\mathrm{kJ} \mathrm{mol}^{-1}\right)$ of methanol oxidation on the Ni-B and Ni-B-Co nanoparticles at different potentials.

\begin{tabular}{|c|c|c|c|c|}
\hline Sample & Ni-B & $\mathrm{Ni}-\mathrm{B}-\mathrm{Co}_{0.02}$ & $\mathrm{Ni}-\mathrm{B}-\mathrm{Co}_{0.05}$ & $\mathrm{Ni}-\mathrm{B}-\mathrm{Co}_{0.1}$ \\
\hline $0.50 \mathrm{~V}$ & 37.69 & 36.54 & 32.88 & 31.84 \\
\hline $0.55 \mathrm{~V}$ & 28.27 & 26.55 & 26.31 & 25.06 \\
\hline $0.60 \mathrm{~V}$ & 25.58 & 23.10 & 22.79 & 22.20 \\
\hline $0.65 \mathrm{~V}$ & 25.43 & 22.26 & 22.01 & 21.35 \\
\hline $0.70 \mathrm{~V}$ & 26.38 & 22.86 & 22.29 & 21.96 \\
\hline
\end{tabular}

From the cyclic voltammograms of the $\mathrm{Ni}-\mathrm{B}$ and $\mathrm{Ni}-\mathrm{B}-\mathrm{Co}_{0.05}$ nanoparticles at different temperatures $(303.15 \mathrm{~K}-333.15 \mathrm{~K})$ in a $1 \mathrm{M} \mathrm{NaOH}$ solution (Figure S4), the calculated $E_{\mathrm{a}}$ values for the oxidation of $\mathrm{Ni}(\mathrm{OH})_{2}$ to $\mathrm{NiOOH}$ at $0.42 \mathrm{~V}$ were determined to be 45.12 and $40.93 \mathrm{~kJ} \mathrm{~mol}^{-1}$, respectively. The addition of Co thus decreased the $E_{\mathrm{a}}$ of the $\mathrm{Ni}(\mathrm{OH})_{2} / \mathrm{NiOOH}$ oxidation on the $\mathrm{Ni}-\mathrm{B}-\mathrm{Co}$ nanoparticles. Compared to the $E_{\mathrm{a}}$ values for the overall methanol oxidation at $0.42 \mathrm{~V}$ on the $\mathrm{Ni}-\mathrm{B}$ and $\mathrm{Ni}-\mathrm{B}-\mathrm{Co}_{0.05}$ nanoparticles (103.59 and $112.20 \mathrm{~kJ} \mathrm{~mol}^{-1}$, respectively) the $E_{\mathrm{a}}$ of the $\mathrm{Ni}(\mathrm{OH})_{2} / \mathrm{NiOOH}$ oxidation was much smaller.

In addition, $A$ is not actually a constant, it is related to the activation entropy $\left(\Delta_{\mathrm{r}} S_{\mathrm{m}}\right)$ of the reaction [42],

$$
A=A^{\prime} e^{\Delta_{\mathrm{r}} S_{\mathrm{m}} / R}
$$

Here, although $E_{\mathrm{a}}$ of $\mathrm{Ni}-\mathrm{B}-\mathrm{Co}_{0.1}$ nanoparticle is lowest, the methanol oxidation peak current is lower than that of the $\mathrm{Ni}-\mathrm{B}-\mathrm{CO}_{0.05}$ nanoparticle. This may be due to the strong adsorption ability of the $\mathrm{Ni} 3 d$ orbital to methanol molecules and intermediate species, resulting in lower activation entropy, so the methanol oxidation peak current is low. 


\section{Discussion}

Unlike crystalline metals, the structures of amorphous alloys contain no long-range ordering of atoms. The local atomic arrangements, therefore, must be well correlated and exhibit a certain degree of short-range order (SRO) and medium-range order (MRO). Gaskell [43] proposed that the basic local structural unit (SRO, nearest-neighbor shell) of the amorphous Ni-B alloy consisted of a tri-capped trigonal prism (TTP) with nine $\mathrm{Ni}$ atoms in the shell (six for the trigonal prism and three for the caps) and one B atom in the center. Although this proposal is similar to the corresponding crystalline compound (Figure 7, bottom right), the atomic arrangement in this report was more arbitrary and irregular [43-45]. The MRO was further proposed to include the efficient packing and connection disorder of TTP units via shared shell atoms (face sharing, edge sharing, and vertex sharing); the fivefold character and icosahedral-like feature of the B-B was proposed (Figure 7, upper right) [44,46,47]. Despite these reports, the structure of the amorphous Ni-B alloy is in reality much more complicated because of the likely random atomic arrangement. Research uncovering this elusive structure remains a significant challenge. Consequently, the structure of the $\mathrm{Ni}(\mathrm{OH})_{2}$ and $\mathrm{NiOOH}$ production on the surface of the amorphous Ni-B alloy is currently unknown. Regarding the effect of Co addition on the structure of $\mathrm{Ni}-\mathrm{B}$, it might be a simple substitution of $\mathrm{Ni}$ with Co due to the relatively low Co content in the Ni-B-Co nanoparticles. Nevertheless, a specific structural investigation on amorphous Ni-B and Ni-B-Co nanoparticles is not within the scope of this paper; instead, we focused on the possible voids, gaps, or cavities formed due to the random atomic arrangement of the amorphous nanoparticles. The presence of these voids, gaps, or cavities in the nanomaterials could allow for the permeation of molecules, such as methanol. At the same time, more catalytically active sites for methanol oxidation could be exposed, which would aid in improving the catalytic activity.

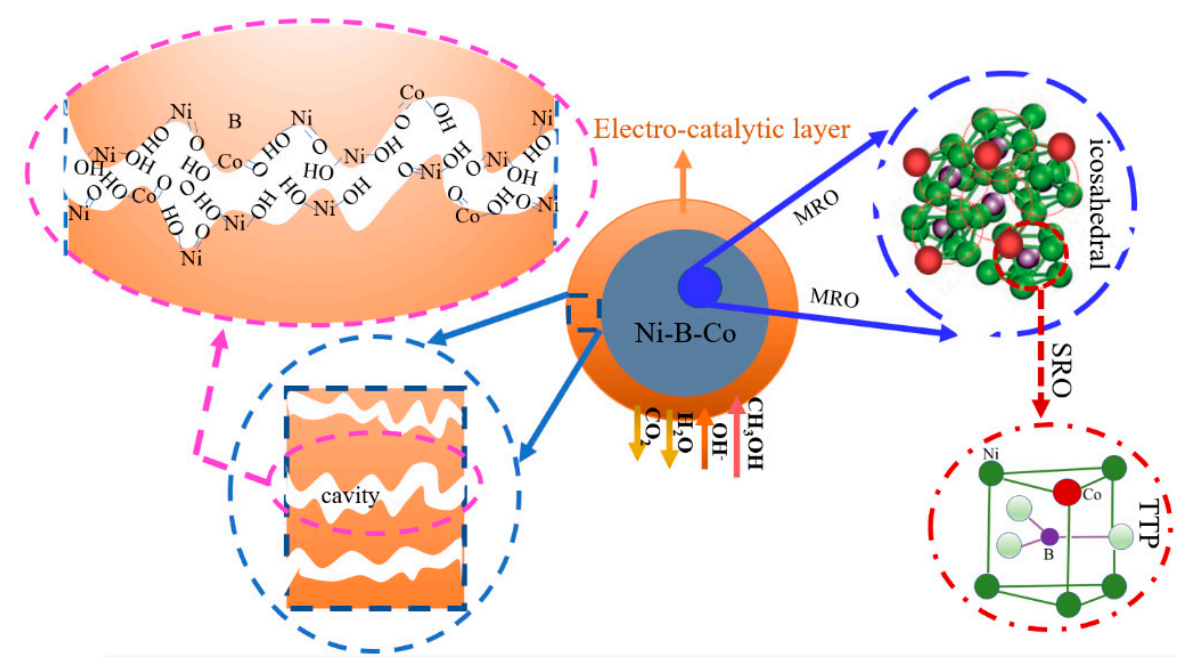

Figure 7. An electrocatalytic layer on the amorphous Ni-B-Co nanoparticles during the methanol oxidation.

The methanol oxidation and reduction peak currents of $\mathrm{NiOOH} / \mathrm{Ni}(\mathrm{OH})_{2}$ appearing in the cathodic sweep varied as the methanol concentration and hydroxide ion concentration increased (Sections 2.3 and 2.4). We hypothesized that a three-dimensional porous conductive layer with a certain thickness was forming on the surface of the amorphous Ni-B and Ni-B-Co nanoparticles via electrochemical oxidation. Figure 7 depicts the proposed electrocatalytic layer formed during methanol oxidation on the amorphous Ni-B-Co nanoparticles. This conductive layer was denoted as an electrocatalytic layer, which served as an interface between the bulk Ni-B (or Ni-B-Co) nanoparticles and corresponding solution. Methanol and hydroxide ions could diffuse freely through the electrocatalytic layer, and the surface could adsorb reactant molecules and ions in the electrolyte, such as methanol or hydroxide ions. In the electrocatalytic layer, active $\mathrm{Ni}(\mathrm{OH})_{2}$ could be electrooxidized to $\mathrm{NiOOH}$, and $\mathrm{NiOOH}$ could then chemically oxidize the adsorbed methanol molecules to release reaction intermediates and $\mathrm{CO}_{2}$. 
Based on the previously discussed effects of methanol concentration and hydroxide concentration on the methanol oxidation current and reaction orders, and literature precedence, we propose the following reaction mechanism of the electrocatalytic oxidation of methanol on Ni-B and Ni-B-Co nanoparticles:

$$
\begin{aligned}
& \mathrm{Ni}^{2+}(\mathrm{OH})_{2} \rightarrow \mathrm{Ni}^{3+}(\mathrm{OH})_{2}+\mathrm{e}^{-} \\
& \mathrm{OH}^{-} \rightarrow\left(\mathrm{OH}^{-}\right)_{\text {ads }} \\
& \mathrm{Ni}^{3+}(\mathrm{OH})_{2}+\left(\mathrm{OH}^{-}\right)_{\mathrm{ads}} \rightarrow \mathrm{Ni}^{3+}(\mathrm{OH})_{3} \\
& \mathrm{Ni}^{3+}(\mathrm{OH})_{3} \rightarrow \mathrm{NiOOH}+\mathrm{H}_{2} \mathrm{O} \\
& \mathrm{CH}_{3} \mathrm{OH} \rightarrow\left(\mathrm{CH}_{3} \mathrm{OH}\right)_{\text {ads }} \\
&\left(\mathrm{CH}_{3} \mathrm{OH}\right)_{\mathrm{ads}}+\mathrm{NiOOH} \rightarrow\left(\mathrm{CH}_{2} \mathrm{O}\right)_{\mathrm{ads}}+\mathrm{Ni}(\mathrm{OH})_{2} \\
&\left(\mathrm{CH}_{3} \mathrm{O}\right)_{\mathrm{ads}}+\mathrm{NiOOH} \rightarrow\left(\mathrm{CH}_{2} \mathrm{O}\right)_{\mathrm{ads}}+\mathrm{Ni}(\mathrm{OH})_{2} \\
&\left(\mathrm{CH}_{2} \mathrm{O}\right)_{\mathrm{ads}}+\mathrm{NiOOH} \rightarrow\left(\mathrm{CHO}_{\mathrm{ads}}+\mathrm{Ni}(\mathrm{OH})_{2}\right. \\
&(\mathrm{CHO})_{\mathrm{ads}}+\mathrm{NiOOH} \rightarrow(\mathrm{CO})_{\mathrm{ads}}+\mathrm{Ni}(\mathrm{OH})_{2} \\
&(\mathrm{CO})_{\mathrm{ads}}+\mathrm{NiOOH}+(\mathrm{OH})_{\mathrm{ads}} \rightarrow \mathrm{CO}_{2}+\mathrm{Ni}(\mathrm{OH})_{2}
\end{aligned}
$$

The whole methanol oxidation process in the electrocatalytic layer involves two major reactions: the electrochemical oxidation of $\mathrm{Ni}(\mathrm{OH})_{2}$ to $\mathrm{NiOOH}$ and the chemical oxidation of adsorbed methanol by $\mathrm{NiOOH}$. Here, we speculated that the oxidation of $\mathrm{Ni}(\mathrm{OH})_{2}$ to $\mathrm{NiOOH}$ consisted of four steps: $\mathrm{Ni}(\mathrm{OH})_{2}$ loses an electron (Equation (6)), $\mathrm{OH}^{-}$is absorbed (Equation (7)) on the surface of the Ni-B and Ni-B-Co nanoparticles, $\mathrm{Ni}^{3+}(\mathrm{OH})_{2}$ binds with $\left(\mathrm{OH}^{-}\right)_{\text {ads }}$ (Equation (8)), and unstable $\mathrm{Ni}^{3+}(\mathrm{OH})_{3}$ is dehydrated (Equation (9)). We then realized that the apparent peak current of methanol oxidation was actually the electrochemical oxidation current of $\mathrm{Ni}(\mathrm{OH})_{2}$ to $\mathrm{NiOOH}$, namely, the formation current of $\mathrm{NiOOH}$. The formation current of $\mathrm{NiOOH}$ depended on the electrode potential and $\mathrm{Ni}^{3+} / \mathrm{Ni}^{2+}$ atomic ratio in the electrocatalytic layer; the higher the electrode potential, the higher the $\mathrm{Ni}^{3+} / \mathrm{Ni}^{2+}$ ratio. Meanwhile, the higher the consumption rate of $\mathrm{NiOOH}$ by methanol, the lower the $\mathrm{Ni}^{3+} / \mathrm{Ni}^{2+}$ ratio; and the lower the $\mathrm{Ni}^{3+} / \mathrm{Ni}^{2+}$ ratio, the faster the formation rate of $\mathrm{NiOOH}$ at the same potential. The above experimental results indicated that the oxidation of $\mathrm{Ni}(\mathrm{OH})_{2}$ to $\mathrm{NiOOH}$ was a precursor step in the methanol oxidation process. Accordingly, it was inferred that methanol oxidation on the surface of the Ni-B and Ni-B-Co nanoparticles involved methanol adsorption (Equation (10)), successive dehydrogenation (Equation (11)-(14)), and oxidation of intermediate species, such as CO (Equation (15)). Here, for the convenience of this discussion, the successive dehydrogenation of adsorbed methanol and oxidation of intermediates were unified into the intermediate consumption step.

Section 2.3 detailed how the peak currents for the methanol oxidation initially increased, then decreased as the methanol concentration increased on both the Ni-B and Ni-B-Co nanoparticles. This effect could be attributed to an increase in the rate of methanol adsorption onto the surface of Ni-B and $\mathrm{Ni}$-B-Co nanoparticles due to the increase in methanol concentration. Taken together, this effect would increase the overall methanol oxidation rate. However, when too many methanol molecules were absorbed onto the surface of the Ni-B and Ni-B-Co nanoparticles at methanol concentrations greater than $1.0 \mathrm{M}$, the adsorption active sites of the hydroxide ions were occupied (Equation (7)), decreasing the formation rate of $\mathrm{NiOOH}$ (Equations (8) and (9)). Under these conditions (1.5 M), the methanol oxidation rate decreased.

Section 2.3 also revealed that the oxidation peaks of $\mathrm{Ni}(\mathrm{OH})_{2} / \mathrm{NiOOH}$ were observed at low methanol concentrations $(0.1-0.2 \mathrm{M})$ and disappeared at high methanol concentrations $(\geq 0.5 \mathrm{M})$. This phenomenon also provided evidence for the oxidation of $\mathrm{Ni}(\mathrm{OH})_{2}$ to $\mathrm{NiOOH}$ being a precursor step that was faster than the rate of intermediate consumption at low methanol concentrations and close or equal to the rate of intermediate consumption at high methanol concentrations. Notably, this 
relationship is in agreement with the control process mechanism of methanol oxidation proposed by Fleischmann et al. [8].

The reduction peak currents of $\mathrm{NiOOH} / \mathrm{Ni}(\mathrm{OH})_{2}$ in the present work (Section 2.3) were also shown to decrease as the methanol concentration increased $(0-1.0 \mathrm{M})$. Here, the reduction peak in the cathodic sweep is attributed to the electrochemical reduction of retaining $\mathrm{NiOOH}$ in the electrocatalytic layer. In the anodic sweep, $\mathrm{NiOOH}$ generation was dependent on the electrode potential and the scan rate, and was gradually consumed by methanol reaction intermediates; in the cathodic sweep, $\mathrm{NiOOH}$ would remain, the remaining amount of which depended mainly on the scan rate and the rate of $\mathrm{NiOOH}$ consumed by methanol reaction intermediates. When the scan rate was constant, the consumption rate of $\mathrm{NiOOH}$ by the intermediates increased as the methanol concentration increased; thus, the higher the methanol concentration, the lower the reduction peak current of $\mathrm{NiOOH}$. However, at $1.5 \mathrm{M}$, the reduction peak current of $\mathrm{NiOOH} / \mathrm{Ni}(\mathrm{OH})_{2}$ was higher than the peak current at $1.0 \mathrm{M}$, which could be the presence of intermediates such as $\mathrm{CO}$ in the electrocatalytic layer that were difficult to oxidize by $\mathrm{NiOOH}$ due to its high adsorption energy. Thus, in the cathodic sweep, there was a greater amount of remaining $\mathrm{NiOOH}$ at $1.5 \mathrm{M}$ than at lower concentrations.

The reduction peak currents of $\mathrm{NiOOH} / \mathrm{Ni}(\mathrm{OH})_{2}$ were higher for the amorphous Ni-B-Co nanoparticles than the Ni-B nanoparticle system (Table 3 and Figure 4). The Co doping increased the electron cloud density of the $\mathrm{Ni}$ atoms, making the surface $\mathrm{Ni}$ atoms prone to losing electrons, which accelerated the rate of the $\mathrm{Ni}^{3+}(\mathrm{NiOOH})$ generation reaction (Equation (5)). As a result, the amount of $\mathrm{NiOOH}$ remaining in the cathodic sweep on the surface of the Ni-B-Co nanoparticles was greater than the Ni-B system. When the Co content increased further, it did not aid in accelerating the rate of $\mathrm{NiOOH}$ generation or in increasing the residual amount of $\mathrm{NiOOH}$, but instead generated excess $\mathrm{CoOOH}$ that could not be reduced by methanol. In addition, the onset potentials of $\mathrm{NiOOH}$ reduction on the Ni-B and Ni-B-Co nanoparticles shifted in the negative direction because a gradual decrease in the remaining $\mathrm{NiOOH}$ resulted in a gradual decrease in the $\mathrm{Ni}^{3+} / \mathrm{Ni}^{2+}$ ratio as the methanol concentration increased up to $1.0 \mathrm{M}$.

\section{Experimental}

\subsection{Preparation of the Catalyst Nanoparticles and Working Electrode}

The preparation of the catalyst was the same as our previous work [23]. Pure water was obtained from the water purification machine in the laboratory (Chengdu, China). Potassium borohydride $\left(\mathrm{KBH}_{4}\right)$ and polyvinylpyrrolidone (PVP)-k30 served as a reductant and a protective reagent in the reaction, respectively. First, $x \mathrm{~g} \mathrm{CoCl}_{2} \cdot 6 \mathrm{H}_{2} \mathrm{O}, 4.04 \mathrm{~g} \mathrm{NiCl}_{2} \cdot 6 \mathrm{H}_{2} \mathrm{O}$ and $2.00 \mathrm{~g}$ PVP were mixed in $20 \mathrm{~mL}$ of pure water under ultrasonication conditions. Here, the concentration of $\mathrm{Co}(x=0,0.08,0.20$, and $0.40 \mathrm{~g}$ ) was varied, but the other components were held constant. Then, a $40 \mathrm{~mL}$ solution of $\mathrm{NaOH}$ $(0.96 \mathrm{~g})$ and $\mathrm{KBH}_{4}(5.50 \mathrm{~g})$ dissolved in $60 \mathrm{~mL}$ of pure water was added dropwise to the above salt solution at a $1 \mathrm{~mL} \mathrm{~min}^{-1}$ rate. Vigorously stirred this reaction system for $5 \mathrm{~h}$ at $0{ }^{\circ} \mathrm{C}$. Separated the black precipitate by centrifugation, thoroughly washed with pure water and absolute alcohol, and in a vacuum oven dried for $12 \mathrm{~h}$ at $80{ }^{\circ} \mathrm{C}$. Labeled the prepared catalysts as $\mathrm{Ni}-\mathrm{B}, \mathrm{Ni}-\mathrm{B}-\mathrm{Co}_{0.02}, \mathrm{Ni}-\mathrm{B}-\mathrm{Co}_{0.05}$, and Ni-B-Co $\mathrm{Co}_{0.1}$, where $0.02,0.05$, and 0.1 correspond to the $\mathrm{Co}^{2+} / \mathrm{Ni}^{2+}$ molar ratios.

Next, prepared the catalyst mixture with $8 \mathrm{mg}$ of the catalyst nanoparticles, $12 \mathrm{mg}$ of Vulcan XC-72 carbon black, $2.5 \mathrm{~mL}$ of water, $2.5 \mathrm{~mL}$ of absolute alcohol, and $125 \mu \mathrm{L}$ of Nafion solution. Dispersed ultrasonically the mixture for $15 \mathrm{~min}$ to form a homogeneous ink. Then dropped $10 \mu \mathrm{L}$ of the ink onto the glassy carbon working electrode $(\varphi=6 \mathrm{~mm})$ with a micropipette, dried using an infrared lamp. Subsequently, coat $10 \mu \mathrm{L}$ of $1 \%$ Nafion solution diluted with 2-propanol to the catalyst surface and then dried.

\subsection{Physical and Electrochemical Characterizations}

The prepared catalysts were characterized by a TJA Atomscan 16 inductively coupled plasma (ICP) spectrometer, a Tecnai G2-F20 field emission transmission electron microscope (TEM) at $200 \mathrm{kV}$, and a 
Netzsch 200F3 differential scanning calorimetry (DSC) at a heating rate of $10^{\circ} \mathrm{C} \mathrm{min}^{-1}$ under a pure nitrogen atmosphere. The electrocatalytic activity was tested by a multichannel VMP2 electrochemical workstation (Princeton, NJ, USA). In a standard three-electrode system, a platinum plate (Pt) is used as the counter electrode and a mercury-mercury oxide $(\mathrm{Hg} / \mathrm{HgO})$ electrode as reference electrodes. Cyclic voltammetry $(\mathrm{CV})$ measurements between 0 and $0.85 \mathrm{~V}$ at $10 \mathrm{mV} \mathrm{s}^{-1}$ at $30.0^{\circ} \mathrm{C}$ were recorded in $1.0 \mathrm{M}$ $\mathrm{NaOH} / x \mathrm{M} \mathrm{CH}_{3} \mathrm{OH}(x=0.10-1.50)$ and in $1.0 \mathrm{M} \mathrm{CH}_{3} \mathrm{OH} / y \mathrm{M} \mathrm{NaOH}(\mathrm{y}=0.1-2)$ solutions to measure the methanol and hydroxyl ion reaction orders, respectively. Additionally, to monitor the temperature effects on the methanol performance, $\mathrm{CV}$ experiments were carried out at different temperatures $\left(30.0-70.0^{\circ} \mathrm{C}\right.$ ) between 0 and $0.85 \mathrm{~V}$ in $1.0 \mathrm{M} \mathrm{NaOH} / 1.0 \mathrm{M} \mathrm{CH}_{3} \mathrm{OH}$ electrolyte at $10 \mathrm{mV} \mathrm{s}^{-1}$.

\section{Conclusions}

The electrocatalytic reaction mechanism of methanol oxidation catalyzed by amorphous Ni-B and Ni-B-Co nanoparticles in alkaline media was investigated. The addition of Co was shown to enhance the thermostability, the diffusion coefficients $\left(D_{0}\right)$, and the catalytic activity of the Ni-B-Co nanoparticles for methanol oxidation. When the Co content was too high, however, the catalytic activity of the Ni-B-Co nanoparticles decreased. The most suitable catalyst was determined to be the $\mathrm{Ni}-\mathrm{B}-\mathrm{Co}_{0.05}$ nanoparticles. The reaction orders of methanol during the oxidation reaction were experimentally determined to be 0.51 , $0.51,0.57$, and 0.45 for the Ni-B, Ni-B-Co $\mathrm{C}_{0.02}, \mathrm{Ni}-\mathrm{B}-\mathrm{Co}_{0.05}$, and Ni-B-Co $\mathrm{C}_{0.1}$ nanoparticles, respectively. The reaction orders for the hydroxide ions in the $\mathrm{Ni}-\mathrm{B}, \mathrm{Ni}-\mathrm{B}-\mathrm{Co}_{0.02}, \mathrm{Ni}-\mathrm{B}-\mathrm{Co}_{0.05}$, and $\mathrm{Ni}-\mathrm{B}-\mathrm{Co}_{0.1}$ nanoparticles systems were $0.92,0.81,0.89$, and 0.84 , respectively. Furthermore, the activation energy $\left(E_{\mathrm{a}}\right)$ values for the Ni-B methanol oxidation system was lower than the Ni-B-Co nanoparticles. We also observed a pronounced effect of hydroxide ion concentration on the rate of methanol oxidation. Increasing the adsorption capacity of the catalyst surface for hydroxide ions by doping new elements might be a viable strategy for improving the activity of the catalysts further. In addition, the oxidation process of $\mathrm{Ni}(\mathrm{OH})_{2}$ to $\mathrm{NiOOH}$ was determined to be a precursor electrochemical step for methanol oxidation. Lastly, an electrocatalytic reaction mechanism for methanol oxidation catalyzed by $\mathrm{Ni}-\mathrm{B} / \mathrm{Ni}-\mathrm{B}-\mathrm{Co}$ nanoparticles was proposed, which was consistent with all of our experimental results. Taken together, our study provides new understanding on the methanol oxidation reaction mechanism catalyzed by amorphous $\mathrm{Ni}-\mathrm{B}$ and Ni-B-Co nanoparticles and may aid in furthering the development of efficient and sustainable electrocatalytic systems.

Supplementary Materials: The following are available online at http://www.mdpi.com/2073-4344/9/9/749/s1, Figure S1: XRD patterns of Ni-B and Ni-B-Co nanoparticles, Figure S2: The particle size distribution histograms of Ni-B(a), Ni-B-Co0.02(b), Ni-B-Co0.05(c), and Ni-B-Co0.1(d) nanoparticles from TEM, Figure S3: XPS spectra of Ni2p (a) and B1s (b) for Ni-B and Ni-Co-B nanoparticles, Figure S4: Cyclic voltammograms on Ni-B and Ni-B-Co0.05 nanoparticles in a range from 0.0 to $0.8 \mathrm{~V}$ at different temperatures in $1 \mathrm{M} \mathrm{NaOH}$ solution, Table S1: The bulk and surface atomic ratios of Ni-B and Ni-B-Co nanoparticles.

Author Contributions: All the authors contributed to the manuscript.

Funding: This research received no external funding.

Conflicts of Interest: The authors declare no conflict of interest.

\section{References}

1. Joghee, P.; Malik, J.N.; Pylypenko, S.; O'Hayre, R. A review on direct methanol fuel cells -In the perspective of energy and sustainability. MRS Energy Sustain. 2015, 2, 1-31. [CrossRef]

2. Feng, Y.; Liu, H.; Yang, J. A selective electrocatalyst-based direct methanol fuel cell operated at high concentrations of methanol. Sci. Adv. 2017, 3, e1700580. [CrossRef] [PubMed]

3. Huang, W.J.; Wang, H.T.; Zhou, J.G.; Wang, J.; Duchesne, P.N.; Muir, D.; Zhang, P.; Han, N.; Zhao, F.P.; Zeng, M.; et al. Highly active and durable methanol oxidation electrocatalyst based on the synergy of platinum-nickel hydroxide-graphene. Nat. Commun. 2015, 6, 10035. [CrossRef] [PubMed]

4. Xu, G.F.; Li, Z.F.; Wang, S.W.; Yu, X.J. Planar polyphthalocyanine cobalt absorbed on carbon black as stable electrocatalysts for direct methanol fuel cell. J. Power Sources 2010, 195, 4731-4735. [CrossRef] 
5. Singh, R.N.; Sharma, T.; Singh, A.; Mishra, D.; Tiwari, S.K. Perovskite-type La2-xSrxNiO4 $(0 \leq x \leq 1)$ as active anode materials for methanol oxidation in alkaline solutions. Electrochim. Acta 2008, 53, 2322-2330. [CrossRef]

6. Zhang, S.J.; Zheng, Y.X.; Yuan, L.S.; Zhao, L.H. Ni-B amorphous alloy nanoparticles modified nanoporous $\mathrm{Cu}$ toward ethanol oxidation in alkaline medium. J. Power Sources 2014, 247, 428-436. [CrossRef]

7. Manivasakan, P.; Ramasamy, P.; Kim, J. Use of urchin-like NixCo3-xO4 hierarchical nanostructures based on non-precious metals as bifunctional electrocatalysts for anion-exchange membrane alkaline alcohol fuel cells. Nanoscale 2014, 6, 9665-9672. [CrossRef] [PubMed]

8. Fleischmann, M.; Korinek, K.; Pletcher, D. The Kinetics and Mechanism of the Oxidation of Amines and Alcohols at Oxide-covered Nickel, Silver, Copper, and Cobalt Electrodes. J. Chem. Soc. Perkin Trans. 1972, 2, 1396-1403. [CrossRef]

9. Wang, J.; Teschner, D.; Yao, Y.Y.; Huang, X.; Willinger, M.; Shao, L.D.; Schlögl, R. Fabrication of nanoscale $\mathrm{NiO} / \mathrm{Ni}$ heterostructures as electrocatalysts for efficient methanol oxidation. J. Mater. Chem. A 2017, 5, 9946-9951. [CrossRef]

10. Candelaria, S.L.; Bedford, N.M.; Woehl, T.J.; Rentz, N.S.; Showalter, A.R.; Pylypenko, S.; Bunker, B.A.; Lee, S.; Reinhart, B.; Ren, Y.; et al. Multi-Component Fe-Ni hydroxide nanocatalyst for oxygen evolution and methanol oxidation reactions under alkaline conditions. ACS Catal. 2017, 7, 365-379. [CrossRef]

11. Wang, W.Y.; Li, R.F.; Hua, X.; Zhang, R. Methanol electrooxidation on glassy carbon electrode modified with bimetallic $\mathrm{Ni}(\mathrm{II}) \mathrm{Co}(\mathrm{II})$ salen complexes encapsulated in mesoporous zeolite A. Electrochim. Acta 2015, 163, 48-56. [CrossRef]

12. Wang, W.Y.; Li, R.F.; Zhang, R.; Ma, J.H.; Wang, B.C. Electrocatalytic oxidation of methanol on glassy carbon electrode modified with nickel-manganese salen complexes encapsulated in mesoporous zeolite A. J. Electroanal. Chem. 2015, 742, 110-121. [CrossRef]

13. Luo, Q.; Peng, M.Y.; Sun, X.P.; Asiri, A.M. In situ growth of nickel selenide nanowire arrays on nickel foil for methanol electro-oxidation in alkaline media. RSC Adv. 2015, 5, 87051-87054. [CrossRef]

14. Luo, Q.; Peng, M.Y.; Sun, X.P.; Asiri, A.M. Hierarchical nickel oxide nanosheet@nanowire arrays on nickel foam: An efficient 3D electrode for methanol electro-oxidation. Catal. Sci. Technol. 2016, 6, 1157-1161. [CrossRef]

15. Yuan, Q.B.; Duan, D.H.; Ma, Y.H.; Wei, G.Q.; Zhang, Z.L.; Hao, X.G.; Liu, S.B. Performance of nano-nickel core wrapped with Pt crystalline thin film for methanol electro-oxidation. J. Power Sources 2014, 245, 886-891. [CrossRef]

16. Rahim, M.A.A.; Hameed, R.M.A.; Khalil, M.W. Nickel as a catalyst for the electro-oxidation of methanol in alkaline medium. J. Power Sources 2004, 134, 160-169. [CrossRef]

17. Zheng, Y.X.; Yao, S.B.; Zhou, S.M. Electrocatalytic oxidation of methanol at the nano Ni-B amorphous alloy powder microelectrode. Electrochem. Acta Phys. -Chim. Sin. 2007, 13, 307-311.

18. Yuan, L.S.; Zheng, Y.X.; Jia, M.L.; Zhang, S.J.; Wang, X.L.; Peng, C. Nanoporous nickel-copper-phosphorus amorphous alloy film for methanol electro-oxidation in alkaline medium. Electrochim. Acta 2015, 154, 54-62. [CrossRef]

19. Hassan, H.B.; Hamid, Z.A. Electroless Ni-B supported on carbon for direct alcohol fuel cell applications. Int. J. Hydrogen Energe 2011, 36, 849-856. [CrossRef]

20. Cao, H.Z.; Wang, Z.W.; Hou, G.Y.; Zheng, G.Q. $\mathrm{TiO}_{2}$ nanotube-supported amorphous Ni-B electrode for electrocatalytic oxidation of methanol. Surf. Coat. Technol. 2010, 205, 885-889. [CrossRef]

21. Hameed, R.M.A.; El-Khatib, K.M. Ni-P and Ni-Cu-P modified carbon catalysts for methanol electro-oxidation in $\mathrm{KOH}$ solution. Int. J. Hydrogen Energe 2010, 35, 2517-2529. [CrossRef]

22. Tong, Y.Y.; Gu, C.D.; Zhang, J.L.; Huang, M.L.; Tang, H.; Wang, X.L.; Tu, J.P. Three-dimensional astrocyte-network Ni-P-O compound with superior electrocatalytic activity and stability for methanol oxidation in alkaline environments. J. Mater. Chem. A 2015, 3, 4669-4678. [CrossRef]

23. Wu, F.H.; Zhang, Z.L.; Zhang, F.S.; Duan, D.H.; Li, Y.; Wei, G.Q.; Liu, S.B.; Yuan, Q.B.; Wang, E.Z.; Hao, X.G. Exploring the role of cobalt in promoting the electroactivity of amorphous $\mathrm{Ni}-\mathrm{B}$ nanoparticles toward methanol oxidation. Electrochim. Acta 2018, 287, 115-123. [CrossRef]

24. French, H.M.; Henderson, M.J.; Hillman, A.R.; Vieil, E. Ion and solvent transfer discrimination at a nickel hydroxide film exposed to $\mathrm{LiOH}$ by combined electrochemical quartz crystal microbalance (EQCM) and probe beam deflection (PBD) techniques. J. Electroanal. Chem. 2001, 500, 192-207. [CrossRef]

25. French, H.M.; Henderson, M.J.; Hillman, A.R.; Vieil, E. Temporal resolution of ion and solvent transfers at nickel hydroxide films exposed to LiOH. Solid State Ion. 2002, 150, 27-37. [CrossRef] 
26. Taraszewska, J.; Rosłonek, G. Electrocatalytic oxidation of methanol on a glassy carbon electrode modified by nickel hydroxide formed by ex situ chemical precipitation. J. Electroanal. Chem. 1994, 364, 209-213. [CrossRef]

27. Barakat, N.A.M.; Abdelkareem, M.A.; Yousef, A.; Al-Deyab, S.S.; El-Newehy, M.; Kim, H.Y. Cadmium-doped cobalt/carbon nanoparticles as novel nonprecious electrocatalyst for methanol oxidation. Int. J. Hydrogen. Energe. 2013, 38, 3387-3394. [CrossRef]

28. Deng, J.F.; Yan, J.; Sheng, S.S.; Chen, H.R.; Xiong, G.X. The study of ultrafine Ni-B and Ni-P amorphous alloy powders as catalysits. J. Catal. 1994, 150, 434-438. [CrossRef]

29. Zhang, X.X.; Ma, A.Z.; Mu, X.H.; Min, E.Z. Selective hydrogenation of reformate oils over amorphous $\mathrm{NiB} / \mathrm{SiO} 2$ catalyst. Catal. Today 2002, 74, 77-84. [CrossRef]

30. Das, A.K.; Layek, R.K.; Kim, N.H.; Jung, D.; Lee, J.H. Reduced graphene oxide (RGO)-supported NiCo2O4 nanoparticles: An electrocatalyst for methanol oxidation. Nanoscale 2014, 6, 10657-10665. [CrossRef]

31. Wang, W.; Chu, Q.X.; Zhang, Y.N.; Zhu, W.; Wang, X.F.; Liu, X.Y. Nickel foam supported mesoporous $\mathrm{NiCo} 2 \mathrm{O} 4$ arrays with excellent methanol electro-oxidation performance. New J. Chem. 2015, 39, 6491-6497. [CrossRef]

32. Tong, Y.Y.; Gu, C.D.; Zhang, J.L.; Tang, H.; Li, Y.; Wang, X.L.; Tu, J.P. Urchin-like Ni-Co-P-O nanocomposite as novel methanol electro-oxidation materials in alkaline environment. Electrochim. Acta 2016, 187, 11-19. [CrossRef]

33. Wang, X.Y.; Yan, J.; Zhang, Y.S.; Yuan, H.T.; Song, D.Y. Cyclic voltammetric studies of pasted nickel hydroxide electrode microencapsulated by cobalt. J. Appl. Electrochem. 1998, 28, 1377-1382. [CrossRef]

34. Yu, Z.B.; Qiao, M.H.; Li, H.X.; Deng, J.F. Preparation of amorphous NiCoB alloys and the effect of cobalt on their hydrogenation activity. Appl. Catal. A Gen. 1997, 163, 1-13. [CrossRef]

35. Xie, S.H.; Li, H.X.; Li, H.; Deng, J.F. Selective hydrogenation of stearonitrile over Ni-B/SiO2 amorphous catalysts in comparison with other Ni-based catalysts. Appl. Catal. A Gen. 1999, 189, 45-52. [CrossRef]

36. Xie, S.; Tong, X.L.; Jin, G.Q.; Qin, Y.; Guo, X.Y. CNT-Ni/SiC hierarchical nanostructures: Preparation and their application in electrocatalytic oxidation of methanol. J. Mater. Chem. A 2013, 1, 2104-2109. [CrossRef]

37. Velázquez-Palenzuela, A.; Centellas, F.; Garrido, J.A.; Arias, C.; Rodríguez, R.M.; Brillas, E.; Cabot, P.L. Kinetic analysis of carbon monoxide and methanol oxidation on high performance carbon-supported $\mathrm{Pt}-\mathrm{Ru}$ electrocatalyst for direct methanol fuel cells. J. Power Sources 2011, 196, 3503-3512. [CrossRef]

38. Xu, C.W.; Hu, Y.H.; Rong, J.H.; Jiang, S.P.; Liu, Y.L. Ni hollow spheres as catalysts for methanol and ethanol electrooxidation. Electrochem. Commun. 2007, 9, 2009-2012. [CrossRef]

39. Yu, E.H.; Scott, K.; Reeve, R.W.; Yang, L.X.; Allen, R.G. Characterisation of platinised Ti mesh electrodes using electrochemical methods: Methanol oxidation in sodium hydroxide solutions. Electrochim. Acta 2004, 49, 2443-2452. [CrossRef]

40. Döner, A.; Telli, E.; Kardaş, G. Electrocatalysis of Ni-promoted Cd coated graphite toward methanol oxidation in alkaline medium. J. Power Sources 2012, 205, 71-79. [CrossRef]

41. Cohen, J.L.; Volpe, D.J.; Abruña, H.D. Electrochemical determination of activation energies for methanol oxidation on polycrystalline platinum in acidic and alkaline electrolytes. Phys. Chem. Chem. Phys. 2007, 9, 49-77. [CrossRef] [PubMed]

42. Peter, A.; Julio, P. Physical Chemistry; Oxford University Press: Oxford, UK, 2006; pp. 883-884.

43. Gaskell, P.H. A new structural model for transition metal-metalloid glasses. Nature 1978, 276, 484-485. [CrossRef]

44. Sheng, H.W.; Luo, W.K.; Alamgir, F.M.; Bai, J.M.; Ma, E. Atomic packing and short-to-medium-range order in metallic glasses. Nature 2006, 439, 419-425. [CrossRef] [PubMed]

45. Dubois, J.M.; Gaskell, P.H.; Caër, G.L. A model for the structure of metallic glasses based on chemical twinning. Proc. R. Soc. Lond. A 1985, 402, 323-357. [CrossRef]

46. Luo, W.K.; Sheng, H.W.; Ma, E. Pair correlation functions and structural building schemes in amorphous alloys. Appl. Phys. Lett. 2006, 89, 131927. [CrossRef]

47. Cheng, Y.Q.; Ma, E. Atomic-level structure and structure-property relationship in metallic glasses. Prog. Mater. Sci. 2011, 56, 379-473. [CrossRef]

(C) 2019 by the authors. Licensee MDPI, Basel, Switzerland. This article is an open access article distributed under the terms and conditions of the Creative Commons Attribution (CC BY) license (http://creativecommons.org/licenses/by/4.0/). 